Max-Planck-Institut für demografische Forschung

Max Planck Institute for Demographic Research

Konrad-Zuse-Strasse 1 - D-18057 Rostock - GERMANY

Tel +49 (0) 3812081 - 0; Fax +49 (0) 3812081 - 202;

http://www.demogr.mpg.de

MPIDR WORKING PAPER WP 2013-004

MARCH 2013

\title{
The Japanese Family System: \\ Change, Continuity, and Regionality over the Twentieth century
}

Akihiko Kato (katoaki@meiji.ac.jp)

This working paper has been approved for release by: Mikołaj Szołtysek (szoltysek@demogr.mpg.de),

Deputy Head of the Laboratory of Historical Demography.

(C) Copyright is held by the authors.

Working papers of the Max Planck Institute for Demographic Research receive only limited review. Views or opinions expressed in working papers are attributable to the authors and do not necessarily reflect those of the Institute. 
The Japanese Family System:

Change, Continuity, and Regionality over the Twentieth century

Akihiko Kato (katoaki@meiji.ac.jp)

March, 2013 


\begin{abstract}
In Japan, many scholars and policymakers as well as ordinary people, have accepted the family nuclearization theory - that is, that the Japanese family system has changed from a traditional stem family into the modern nuclear or conjugal family in the latter half of the twentieth century. Although the number of nuclear family households doubled during the period of high economic growth (1955-1974), this can be brought about under the stem family principle by a marriage boom among non-heir sons and daughters born in the 1930s and the 1940s, who have many siblings due to the demographic transition. This paper examines continuity, change, and regionality in the Japanese family over the twentieth century, using retrospective longitudinal data from nationally representative survey implemented in 2002. The proportion of couples co-residing with the husband's parent(s) or with the wife's parent(s) at the time of marriage decreased from about 35\% for those born in the 1930s to 20\% for those born in the 1960s. However, the latter cohort started living with their parent(s) soon after marriage, and then over 30\% of them co-reside 10-15 years after marriage, showing a delayed co-residence tendency. The results from a discrete-time logistic regression analysis reveal that the spread of conjugal family ideology, industrialization, and urbanization are the primary causes of the decrease in intergenerational co-residence at marriage. However, these effects start to weaken immediately after marriage and then fade out sooner or later, inconsistent with the nuclearization theory. By contrast, the intergenerational transfer of family property, especially house and/or land, and intergenerational reciprocity have powerful impacts from the time of marriage onward, never weakening with the passing of time. These features are clearer among younger cohorts than among their parental cohorts, suggesting intrinsic forces that form stem families continue to work in depth. Moreover, there is the persistence of the stem family in terms of regionality over the twentieth century, concluding that the Japanese family is still based on the stem family system. The evidence presented in this paper could provide several insights into the family systems of other strong family countries.
\end{abstract}




\section{Introduction}

In Japan, many scholars and policymakers as well as ordinary people, have accepted the family nuclearization theory - that is, that the Japanese family system has changed from the traditional stem family into the modern nuclear or conjugal family in the latter half of the twentieth century. In terms of family law, the "ie family regime," which is the most rigid type of stem family in regard to the rule of sole inheritance prescribed by the Meiji Civil Code (1898 Law No. 9), was abolished by the Civil Code Reform (1947 Law No. 222) after World War II. The new code adopted the idealized model of the conjugal family and the rule of equal inheritance among children. Although the number of nuclear family households increased as the population grew, practices and customs unique to the stem family - in particular, that the married eldest son lives with his parents and eventually inherits the family house and/or land-have been widely observed after postwar reform. In addition, Morgan and Hirosima (1983) argued: "Extended residence is not an anachronism. Rather, it offers an appealing alternative to some of the most modern segments of contemporary Japanese society” (p.269), using data from a 1978 study of wives with pre-school-age children and based on the results from the 1980 Population Census that "extended residence is prevalent in contemporary Japan...nearly 30 percent of households with young children are vertically extended" (p.279). Although it has passed three decades since their argument, has the Japanese stem family been an anachronism yet, or still been an adaptive strategy in the early twenty-first century? Recent family surveys can provide stimulating answers to this question.

In this study, the author examines continuity and change in the Japanese family over the twentieth century and tests the family nuclearization theory conducting an event history analysis on intergenerational co-residence using retrospective longitudinal data from nationally representative life course survey. Then, he investigates the persistence of the stem family in terms of regionality using GIS as well as event history techniques.

\section{- Historical Background}

Rapid industrialization accompanied by high economic growth in postwar Japan induced large-scale domestic migration from agricultural areas to large cities. Population flow to the metropolitan areas of Tokyo, Osaka, and Nagoya started to increase in the mid-1950s, which marked the beginning of the high economic growth period, and rose to its peak during the three years before the Tokyo Olympics in 1964. The annual net inflow to the three metropolitan areas exceeded 0.65 million between 1961 and 1962. Domestic migration slowed down, however, when rapid economic growth ended in the mid-1970s.

The three metropolitan areas attained population increases of over $50 \%$ or more as consequences of migration during the 20-year high economic growth period (1955-1974). On the other hand, areas outside these large cities experienced almost no change in population, owing to the natural population increase. People who migrated from rural to urban areas were 
young - primarily those who had no possibility of succeeding the family business, that is, second and third sons and daughters with few job opportunities near their home village (Kase 1997).

According to the School Basic Survey conducted by the Ministry of Education, Science and Culture, $33 \%$ of junior high and $28 \%$ of senior high school graduates immigrated to work outside their home prefecture in March 1962, the peak year of domestic migration. The percentage was high in western Japan, especially on Kyushu Island (70\%-80\% in Kagoshima and Miyazaki prefectures), the San'in region (60\%-70\% in Shimane and Tottori prefectures), and Shikoku Island (50\%-60\% in Kochi and Ehime prefectures). Over 90\% of those who left their home prefecture obtained employment in one of the three metropolitan areas. Every March during the 1950s and 1960s, a large number of young people aged 15 (or 18) graduated from junior (or senior) high school and left their parental home to go to the large cities.

The migratory generation, especially those born in the 1930s and 1940s, belong to the “demographic transitional generation” (Ito 1994, Ochiai 1994), that is, cohorts who were born in the second phase of the demographic transition, which represented high fertility and low infant mortality, and who had a high number of siblings. According to the 1998 National Family Research of Japan, the average number of siblings (including the respondent) was 5.7 and 4.5 for those born in the 1930s and 1940s, respectively (Kato 2006). In addition, the population size of the "demographic transitional generation” was much larger than that of previous birth cohorts. The Japanese baby-boom cohort (so-called dankai no sedai, born in 1947-1949) also belong to the transitional generation.

Those who left their home prefecture at a young age and obtained a job in one of the urban areas enjoyed about a 10\% annual rise in income, and many married in their 20s. During this period, only $10 \%$ of men and less than $10 \%$ of women maintained their never-married status in their early 30s. (In 2005, 47.1\% of men and 32\% of women in the same age range were never married.) In short, rapid economic growth coupled with the larger cohort size of youth resulted in a marriage boom in the transitional generation (Kato 2011).

Soon after marriage, they had two children on average and formed their own household in the newly developed residential areas. It was inevitable that couples living far away from their parents would form a nuclear family household. Moreover, there was no option but for the wife to become a full-time mother and homemaker in that setting.

Thus, rapid urbanization accompanied by high economic growth had provoked the substantial increase in postwar nuclear families with gender-asymmetric family roles, that is, the husband working as a "salaried man" at a company, with the wife serving as a "full-time housewife." In fact, according to the Population Census, the number of typical nuclear family households, which consisted of “a married couple with their child(ren)," doubled from roughly 7.5 million in 1955 to 15 million in $1980 .^{1}$

\footnotetext{
1 The Population Census defines a household as "a group of persons sharing living quarters and living expenses or a person who lives by himself/herself occupying a dwelling house.” For this reason, the concept of co-residence based upon household statistics is narrower than that of co-residence when used as an everyday conversational term, including cases where parents and the married
} 
These nuclear families identified themselves as the admired "democratic” conjugal family as visualized in popular American TV dramas. They adopted the image (or ideology) of a loving modern family living in their own suburban house filled with electric appliances and then tried to live as such a family. The popular phrase "got my own house with a car but without my mother-in-law" (ie-tsuki, kā-tsuki, baba-nuki) clearly represented their powerful longing. For women of the time, becoming a housewife and stay-at-home mother meant liberation from being a daughter-in-law living and engaging in agricultural work with her mother-in-law. The government and companies strongly supported this new family arrangement.

- Questions about the family nuclearization hypothesis

Most family sociologists have regarded the proliferation of nuclear family households in the latter half of the twentieth century as "family nuclearization." That is, the family system changes from the traditional stem family into the conjugal family (Morioka 1972, 1993, 2005; Meguro 1999, etc.). More precisely, they thought that the Japanese family had changed from the traditional stem family system - in which one married child co-resides with the parents and succeeds or inherits property as an heir-to the modern conjugal family system, in which no married child co-resides with the parents and every child inherits property equally.

The hypothesis of progressive nuclearization of the family has offered a basic theoretical framework to interpret the contemporary family in Japan. This framework has gained general acceptance not only in sociology but across the wider field of social science and policymaking. Some researchers use the term "nuclearization of the family" strictly as a statistical meaning, which refers to the rising number of nuclear family households, and yet such careful terminology is exceptional and found only in limited areas of demography. Generally, the term suggests a fundamental change in the family system, explicitly or implicitly.

However, the numerical predominance of nuclear households in the cross-sectional census data does not necessarily mean a system change in family formation. It is compatible with stem family principle: The eldest son lives with the parents and succeeds or inherits the family property (especially the house and/or land); other sons leave the parental home and obtain their own home. In fact, the number of extended family households has remained stable at around 7 million over the high economic growth period in the data ${ }^{2}$. Most are stem family households succeeded by the married eldest son (or the eldest daughter in some regions) of the transitional demographic generation.

In an agricultural society, stem families force other sons to leave their birthplace and achieve economic independence to make a new home on their own if they have no opportunity to

couple share living quarters but do not share living expenses (Hirosima 1997).

${ }^{2}$ Based on this fact, some family sociologists regard the Japanese family during the period of high economic growth as one with a

"dual structure," encompassing both the stem family and the conjugal family. Emiko Ochiai (1994), for example, has used the phrase "nuclearization of the family without a serious break being made with the ie system." 
marry into another family or establish a branch family with parental support. In fact, they have few opportunities to branch out, because it is very difficult to increase the number of households in the village due to severe restrictions on resources (Aruga 1972).

This scenario is also applicable to nuclear family formation during the high economic growth period. A large number of second and third sons and daughters of the transitional generation branched out on their own and resulted in a larger-scale creation of nuclear households than ever before. Therefore, it is very likely that the Japanese family continued to be based upon the stem family system until the 1970s.

To conclude whether the increase in nuclear families during the high economic growth period resulted in the system change since the 1980s, we should examine the family formation of the generation born and raised in those nuclear families, that is, the post-demographic transitional generation, and compare it with that of the parental generation born in the 1930s and 1940s. This has been possible since the year 2000, when those born in the 1960s reached their 30s. Recent family surveys can provide stimulating answers to this question.

\section{Data and method}

To examine the family nuclearization theory, the author uses data from the National Family Research of Japan Special Survey 2001 (NFRJ-S01). The NFRJ-S01 is a nationally representative family life course survey with stratified two-stage random sampling performed in December 2001. The survey was implemented from January to March 2002 and collected data on life event experiences such as marriage, divorce, childbearing and childrearing, post-marital co-residence and proximate residence, home ownership, employment, elderly care, and migration with detailed information on living conditions and the socioeconomic characteristics of families (NFRJ Committee 2003).

Respondents were women born between 1920 and 1969 (aged 32 to 81 at the end of December 2001). The research strategy intended to obtain family history data from wives to clarify changes and continuities in Japanese families (Kato 2003a). The sample size was 5,000, and the total number of questionnaires completed was 3,475, for a response rate of $69.5 \%$. For the purpose of the present study, the sample is restricted to married women $(3,326)$, excluding the never-married (124) and those whose marriage ages are unknown (25).

The questionnaire inquired about life event histories and was designed in a résumé-type format, which the respondent filled out. As for post-marital co-residence with their parents, respondents could fill in the starting and ending dates (in years) for a maximum of three separate occasions, which covered almost $100 \%$ of all co-residence experiences ${ }^{3}$. There were only 36 cases with missing data on co-residence with the husband's parents and only 22 cases with the wife's parents. It should be noted that the word "co-residence" or "living with" used in the questionnaire

\footnotetext{
3 The proportion of respondents who experienced co-residence only once is 93\% for those with the husband's parent(s) and 96\% for those with the wife's parent(s).
} 
was undefined; it was left to respondents to interpret the meaning based on their own understanding of the word. The NFRJ-S01 extends beyond the limit of the household statistics in the Population Census, broadening the narrower concept of co-residence (i.e., sharing living quarters and expenses) to include that of ordinary people, including some types of "two-household housing" (see note 1). The author comes back to this issue later.

In the following sections, the author conducts descriptive and multivariate analyses using event history techniques. First, he describes the proportion of couples co-residing with their parents over the life course, using cohort comparisons to clarify changes and continuity over the twentieth century. Second, he estimates multivariate event history models to specify the determinants of intergenerational co-residence. Third, he examines intergenerational proximate residence in the same manner as analyses on co-residence, and then conducts a GIS-based analysis to present the regionality of (or two types of) the Japanese stem family.

\section{Co-residence of married couples with their parents over the life course}

- Neolocal residence at marriage

Figure 1 shows the proportion of couples co-residing since marriage with the husband's parent(s) or with the wife's parent(s), by birth cohort using the NFRJ-S01 data. The horizontal axis represents the number of years (year $t$ ) that have passed since marriage, and the vertical axis indicates the percentage of respondents co-residing. The birth cohorts were separated into five groups of 10-year intervals, from those born in the 1920s to those born in the 1960s.

The percentage of co-residing was determined by dividing the number of those living with their parent(s) by the number of those who had remained in their first marriage and had at least one parent alive (out of all four parents) in year t. Those who were divorced, widowed, or had lost all parents were censored and excluded in subsequent calculations. The percentage calculated here can be interpreted as the probability of co-residing with parent(s) or of forming a stem family household in year $t$ under the conditions of intact marriage and with available parent(s).

The proportion of couples co-residing with parent(s) at the time of marriage decreased from about $50 \%$ for those born in the 1920 s to $20 \%$ for those born in the 1960 s, suggesting the spread of a certain kind of neolocality in which a newlywed couple does not live with any parent and instead establishes their own household.

Figure 1 about here

In spite of the relative spread of neolocal residence at marriage, couples of the youngest cohort start living with their parents soon after marriage, and then over $30 \%$ of them co-reside 10-15 years after marriage, almost the same level as that of other cohorts. Because most of the couples are living with the husband's parent(s), we can easily find the same tendency of patrilocal 
co-residence in the graph shown on the left-hand side of Figure 2. By contrast, the proportion of those co-residing with the wife's parent(s) is low overall, with none of the cohorts exceeding $10 \%$ as shown on the right-hand side of Figure 2. Ogawa and Retherford (1997) expected a convergence between the proportion living with the husband's parents and the proportion living with the wife's parents using cross-sectional data. However, a descriptive analysis conducted here presents a divergence among younger cohorts: An upward tendency of patrilocal co-residence and a consistently low level of matrilocal co-residence over the life course. It is, though, possible to find a similar trend of matrilocal co-residence in the 1960s cohort, from $3 \%$ at marriage to $8 \%$ ten years after marriage.

The 1960s cohort thus exhibits delayed co-residence: Couples live separately from their parents at marriage and initiate co-residence several years after marriage. The NFRJ-S01 first confirmed this tendency on a national level (Kato, 2003b) ${ }^{4}$; however, its possibility had already been noted at the end of the 1970s.

Takashi Harada (1978) was the first researcher to argue that the proliferation of nuclear family households during the high economic growth period could be the result of a demographic condition of the marriage boom in the transitional generation with a large number of siblings. By examining the Population Census data thoroughly, Harada found that the relatively young couples often experienced "temporary neolocal residence” for some reason such as employment. He argued that such couples (if the husband is the potential heir) expected to co-reside with parents in the future, paralleled by parents' expectation for them to do so. He then regarded it as "fictitious nuclearization,” without accompanying the demise of the stem family.

Figure 2 about here

- Delayed co-residence after marriage

As stated above, the eldest son traditionally lives with the parents under the stem family principle, suggesting a substantial difference in co-residency between the eldest son and the other sons. The left-hand side of Figure 3 presents the proportion of couples in which the husband is the eldest son living with the husband's parent(s) by the wife's birth cohorts. It shows similar trends as Figure 2 (left) for the whole sample. Although the proportion co-residing at marriage decreases from 56\% for the 1930 s cohort to $25 \%$ for the 1960 s, the delayed co-residence tendency becomes stronger the younger the cohort; the proportion co-residing for the 1960 s cohort reaches $40 \%$ ten years after marriage. In addition, the tendency is also obvious in the 1950s cohort; it rises from $40 \%$ to $50 \%$ during the 20 years since marriage. The 1960s cohort will also catch up to a level of $50 \%$ by 20 years after marriage, as is the case with the 1950s cohort. In spite of a large difference in the

\footnotetext{
${ }^{4}$ James Raymo (2010) also showed a delayed co-residence tendency among couples married in the early 1990s; the proportion of those co-residing with parents increased from 20 percent immediately after marriage to 26 percent 10-14 years after marriage, using data from the 2005 Japanese National Fertility Survey.
} 
probability of co-residence at marriage between the eldest sons of the transitional generation and those of the post-transitional generation, it is likely to converge to the same level ultimately.

It should also be noted that delayed co-residency is distinctive in urban areas, as shown on the right-hand side of Figure 3. Although the level is lower throughout the cohorts than the graph on the left, the delayed co-residence tendency is very clear in cities (large cities, central regional cities, and small regional cities) ${ }^{5}$. In rural areas (agricultural, mountainside, or fishing villages), by contrast, the eldest sons tend to co-reside at marriage. All cohorts remain at a level of around $80 \%$ over the life course when plotting a graph (not shown).

Figure 4 presents the proportion of couples in which the husband is not the eldest son co-residing with the husband's parent(s) on the left side and co-residing with the wife's parent(s) on the right side, respectively. We can easily find differences in intergenerational co-residence between eldest sons and other sons. Comparing the left side of Figure 4 to that of Figure 3, the other sons are much less likely to co-reside patrilocally than the eldest sons. However, they are more likely to co-reside matrilocally than the eldest sons; the proportion of the latter co-residing is only $5 \%$ at the most (not shown in a graph). In addition, there is a tendency toward delayed matrilocal co-residence among other sons in the 1960s cohort.

During the high economic growth period, the second and third sons belong to the demographic transitional generation who left their home villages, migrated to cities, and then married and formed nuclear family households. ${ }^{6}$ It is their eldest sons in the post-transitional generation who live separately at marriage and initiate co-residing with them several years after marriage. On the other hand, the eldest sons in the transitional generation who remained in rural areas had co-resided with their parents since marriage. This behavior has reproduced among the eldest sons in the post-transitional generation.

Figure 3. about here

Figure 4. about here

\section{Determinants of co-residence upon and after marriage}

The decrease in co-residence at the time of marriage suggests the spread of a kind of neolocality. Does this signify a transition to the conjugal family system, or is it merely "fictitious nuclearization”? As for delayed patrilocal co-residence among the eldest sons in the 1950s and

\footnotetext{
5 The region of residence is based on the information on residence when the first child of respondents was around one year old. In cases where respondents had no child at the time of the survey (5.3\% of the sample), values were imputed using the information on the residence at that time.

6 The left-hand side of Figure 4 shows that the proportion of patrilocal co-residence among second and third sons born in the 1920 s is highest at the time of marriage (around 30\%) and then starts to decline over time. Since this cohort married during the period of turbulence immediately after World War II, even second and third sons co-resided due to economic hardship. However, with the beginning of the high economic growth period, they would seek better jobs and migrate from rural areas to regional cities or large cities. In addition, Figure 3 suggests some eldest sons acted in the same manner and left their parental home after marriage. Asako Okui (2011) discussed this topic in detail, conducting a case study of heirs who left home and migrated to the city in the high economic growth period.
} 
1960s cohorts, is this practice based on the principle of traditional stem family formation as in the case of their parents' generation? To address these questions, the author first discusses the theoretical backgrounds and explanatory variables of family nuclearization and stem family formation and then conducts a multivariate event history analysis.

\section{- Conjugal family ideology}

The classical theory of family nuclearization has focused on industrialization and urbanization as the main factors (Ogburn \& Nimkoff, 1955). William Goode (1963), however, conducting a comparative analysis of families in Europe, the United States, and five non-European societies (including Japan), pointed out that industrialization does not straightforwardly lead to nuclearization and that conjugal family ideology works as a crucial factor in the process. Goode suggested that the existence of conjugal family ideology could precede industrialization, by referring to the fact that American puritans defined a husband and wife as loving companions and insisted on choosing spouses independently of parental arrangement in the seventeenth century, one century before the Industrial Revolution. He then argued that when such ideology was introduced in advance, the transition to conjugal families would occur faster when industrialization placed pressure on extended families to separate.

The ideology of the conjugal family prevailed in Japan after World War II. As a consequence of Japan's defeat in the war, the General Headquarters of the Supreme Commander of the Allied Powers (GHQ) suggested to entirely revise the Meiji Civil Code and abolished the "ie family regime," which was based on the samurai family model, the most rigid type of stem family (Kawashima 1948). The new Civil Code, based on the ideals of equality between a husband and wife and equal inheritance, stipulated that the family should be "a conjugal family created by the marriage of one man and one woman and extinguished upon the death of both the man and woman." Thus, the new Civil Code presented "the family that is connected by democratic and equal human relationships" as the ideal family model (Fuse, 1993).

In short, the new Civil Code prescribed the ideal type of conjugal family in the United States, the United Kingdom, and France, which constituted the Allied Powers, whereas the Old Civil Code prescribed the ideal type of stem family in the samurai warrior class of Japan. The conjugal family ideology legitimated by the Civil Code may have had a substantial impact on intergenerational living arrangements (Meguro, 1999). However, the young people in those days might have been influenced by American television dramas depicting conjugal companionships rather than by the change in the law.

The theory of the modern family, developed in the United States and Europe in the 1970s, represented sentimental aspects of family relationships as a more modern element of conjugal family ideology (Yamada, 1994). For example, Edward Shorter (1975) argued that "the revolution in sentiment," which took place in nineteenth-century Western Europe, gave birth to the modern nuclear family. "The revolution in sentiment" refers to a dramatic change in attitudes involving the 
emergence of "romantic love," "maternal love," and "a private domesticity” separated from the surrounding community.

The young people of postwar Japan soaked up, via the media, the ideology of the conjugal family, which was flavored with sentimentalism, as pointed out by Shorter. This could be one reason for the decrease in intergenerational co-residence at marriage, especially among those born in the 1960s.

To measure conjugal family ideology, the author utilizes the experience of love marriage and the type of go-between ${ }^{7}$ at a wedding ceremony. The former has three categories: arranged marriage, love marriage, and other or unknown. For the latter, the original eleven categories are collapsed into five categories: husband's kin or neighbor, someone from (related to) husband's work or school, someone from wife's side (including kin, neighbor, or someone related to work or school), no go-between, and no wedding ceremony ${ }^{8}$. These two items were measured with the intention of capturing changes in the way people subjectively define marriage. In the NFRJ-S01, attitudinal items were measured objectively rather than subjectively through relevant behaviors, because it collected longitudinal data retrospectively. Most people can recall the date and place of their life events, while few people can recall what they precisely thought at that time.

It can be considered that the more people are influenced by conjugal family ideology, the more they will tend to avoid an arranged marriage and seek a love marriage instead. In fact, there was a continuous increase in love marriages in Japan in the latter half of the twentieth century. As shown in Table 1, the proportion of love marriages rose fourfold, from $20 \%$ in the 1940 s to $82 \%$ in the 1990s marriage cohort. ${ }^{9}$

Table 1 about here

On the other hand, the wedding ceremony is an occasion and opportunity for the marriage to be acknowledged socially, as people who are closely related to the bride are invited, and thus indicating what kind of social relations the newlywed couple has. Of particular importance is the go-between, who is a type of social parent, not only serving as a matchmaker but also providing private and public supports for the newlywed couple for life; his social position generally reflect the

\footnotetext{
7 A go-between (nakoudo) refers to an individual or couple who introduces potential marital partners to young people of a marriageable age. If such an introduction leads successfully to marriage, the go-between plays a ceremonial role at the wedding, and then act as guardian and support the newlywed couple publicly and privately. Even in the case of a love marriage, the bride and groom often ask someone of standing in their community or company to act as a go-between and play a ceremonial role at the wedding. Even in these cases, the go-between is expected to act as a guardian for the newlywed couple and support them when they face difficulties. The newlywed couple, on the other hand, periodically provides the go-between with gifts and is expected to provide support in some way if the go-between runs into difficulties.

8 As the original question allowed multiple answers, they were converted to a single code in order of descending priorities: a go-between from husband's kin or neighbor, a go-between from husband's work or school, and a go-between from wife's side, no go-between, and no wedding ceremony. "No go-between" includes respondents who have non-customary go-betweens that are neither from the husband nor wife's side. As shown in Table 2, the proportion of those married without a wedding ceremony rises in the 1940s and 1950s, but this could be a result of the turbulence during and after World War II.

9 The analytic sample size of Tables 1 to 6 is 3,310, excluding those who married prior to 1940 (5) and those who married after 2000 (11) for a cohort comparison.
} 
characteristics of the social relations that the couple will form together. In other words, looking at whether a newlywed couple held a wedding ceremony, whether the marriage was (semi-)arranged by a go-between (or go-betweens), and whether the go-between was a kin/neighbor or related to the bride or groom's company/school, we can determine whether the couple lives in a modern "private domesticity" or has close ties with the traditional community or modern company. In fact, Table 2 shows a transition in the type of go-between, from those belonging to kin or a neighboring community to those related to the company or school. It also shows a rise in marriages not involving a customary go-between.

Table 2 about here

- Industrialization and urbanization

As stated above, the classical theory of family nuclearization has primarily focused on industrialization and urbanization, the change from an agrarian society to an industrial and informational society. It posited a functional fit between social subsystems: The extended family would functionally fit agriculture with geographically immobile self-employed peasants, whereas the conjugal family would functionally fit modern industry with highly mobile workers. Industrialization also demands a high level of knowledge, accompanying the spread of higher education. It is thus reasonable to use employment status and educational attainment as measures of industrialization. Categories and distribution of these two measures are shown in Table 3 for the former and Table 4 for the latter, respectively ${ }^{10}$. It is easy to see the rapid increases in both company employment and higher education over the latter half of the twentieth century.

It should be noted here that many wives exit the labor force at marriage or prior to the birth of their first child and return to the labor force after the childrearing period, typically when the youngest child reaches school age. In estimating multivariate event history models, therefore, the employment status of the wife is included as a time-varying variable constructed from the employment history.

Table 3 about here

Table 4 about here

Urban or rural residence is often used as a measure of urbanization. The NFRJ-S01 includes information on the city size in which respondents reside in the early years of marriage: rural (agricultural, mountainside, or fishing) village, small regional city, and large city or central regional city. ${ }^{11}$ As shown in Table 5, their distributions by marriage cohort reveal that over the latter

10 Given the gender-asymmetric family roles, different categories are used for the husband and wife.
11 See also note 5. 
half of the last century, the number of residents in rural villages fell by one-third, while that in large cities conversely doubled.

The spread of conjugal family ideology (Tables 1 and 2), the increases in both corporate employment (Table 3) and higher education (Table 4) accompanied by industrialization, and urbanization (Table 5), all appear to be associated with the decrease in intergenerational co-residence at marriage.

Table 5 about here

øHome ownership, succession/inheritance, and intergenerational reciprocity

As discussed earlier, in the traditional stem family system, one of the married children-typically the eldest son-lives with his parents as an heir and succeeds the family property, especially a house and/or a plot of land. By contrast, in the modern conjugal family system, none of the married children live with their parents or succeed the property exclusively, which is eventually divided and inherited among all the children after the death of their parents. Therefore, we can examine the family nuclearization hypothesis in terms of succession and/or inheritance, analyzing the association between the intergenerational transfer of family property and parent-child co-residence.

To measure the intergenerational transfer, the NFRJ-S01 asked respondents questions about the provision from parents, when the couple obtained their first home, including monetary assets as well as the house and/or land. Table 6 presents the distribution of home ownership and parental provision by marriage cohort. Because the number of those who experienced home ownership rises over time, the distribution 12 years after marriage is displayed in view of delayed co-residence. It should be noted that home ownership is not limited to a detached house but includes one lot of apartment houses (partitioned ownership of condominiums).

Interestingly, we can see a similar trend with delayed co-residency: Decreases in home ownership at the same time of marriage among recent marriage cohorts have been offset to a large degree by increases in the parental provision, especially financial support. On the other hand, home ownership without any provision from parents peaked in the high economic growth period and declined thereafter.

The multivariate models include the measure as a time-varying variable to examine the association between the intergenerational transfer of family property and co-residence. This variable has six categories: not yet own, own upon marriage, own without any provision, own with the provision of house and/or land from husband's side, own with the provision of financial support from husband's side, own with any provision (one or more of house, land, and financial support) from wife's side. If respondents were provided both house/land and financial support, the former was coded prior to the latter. Also, if respondents were provided from both the husband's side and the wife's side, the former was coded prior to the latter.

As a measure of the heir couple, the author constructed a variable that combined the birth 
order of the husband (whether he is the eldest son or not) and the birth order of the wife (whether she is the eldest daughter or not): other son and other daughter, eldest son and other daughter, other son and eldest daughter, eldest son and eldest daughter. To estimate the effect of the heir, the number of siblings of the husband and wife should be controlled, because sibling size might be negatively associated with co-residence.

Intergenerational reciprocity, especially long-term exchange of housing, elderly care, and childcare (grandparenting), has been well documented in the United States and Europe since Morgan and Hirosima (1983) pointed it out, while it has long since been common knowledge not only among scholars but also among older generations in Japan. Thus, the need for elderly care and childcare will be positively associated with co-residence. To examine the intergenerational reciprocity, two measures are used as time-varying variables in the models. One is an indicator of whether both parents are alive or not with three categories: both parents alive, mother only alive, and father only alive. If the father or mother passes away, the likelihood of co-residing with the parent left behind will increase in order for care to be provided. The other is the age of the youngest child with four categories: not yet have a child, aged 0-6, aged 7-12, and aged 13 or older. If the couple has young children, the likelihood of intergenerational co-residence will increase because of the need for grandparenting.

Table 6 about here

n Discrete-time logistic regression model for patrilocal co-residence

In testing the family nuclearization hypothesis, this study estimates discrete-time logistic regression models for intergenerational co-residence. This method is suitable for the NFRJ-S01 data, discretely measuring the occurrence of life events in units of years (see Allison, 1984; and Yamaguchi, 1991 for details). The author estimates separate models for patrilocal co-residence and matrilocal co-residence, because there can be some systematic differences in the effects of explanatory variables (suggested by a preliminary analysis). Also, he estimates separate models for co-residence at marriage and after marriage, for both patrilocal co-residence and matrilocal co-residence, as we are interested in the causes of the decrease in co-residence at marriage and a delayed co-residence tendency after marriage. We first focus on the models for patrilocal co-residence in this section and then conduct a multivariate analysis of matrilocal co-residence in the next section.

The co-residence history of the NFR-JS01 data has an indicator of whether the respondent started co-residing at the same time of marriage, that is, upon marriage or after marriage. Using this indicator, the author constructed the binary dependent variables of co-residence upon marriage and after marriage. Other than the abovementioned explanatory variables, the models include the marriage cohort and region of residence in the early years of marriage, controlling period effects and regional differences that cannot be specified by other variables, respectively. In addition, the wife's age at marriage is controlled, as older couples might be less likely to co-reside with parents. 
The models for co-residence after marriage should include the number of years since marriage.

The analytic sample sizes are 2,976 individual respondents for patrilocal co-residence upon marriage and 36,670 person-year observations for after marriage, after dropping cases with missing data on any of the variables in the model. The first and second columns of Table 7 provide descriptive statistics for explanatory and control variables.

The results of the logistic regression models are presented in the third and fourth columns of Table 7 in the form of odds ratios. These figures describe the odds of co-residence in a given category relative to the odds of co-residence in the reference category, thus allowing us to evaluate the effects of explanatory variables. For example, the odds ratios of 0.48 and 1.19 for love marriage couples in the models of co-residence upon marriage and after marriage, respectively, indicate that the odds of co-residence upon marriage relative to arranged marriage couples are about half as large (0.48 times lower) among love marriage couples, whereas after marriage, love marriage couples are 1.2 times more likely to co-reside than arranged marriage couples. The former is statistically significant, but the latter is not significant.

When multiple factors are working simultaneously, such as a love marriage with no wedding ceremony. the relative likelihood of co-residence upon marriage is determined by multiplying two odds ratios $(0.48 \times 0.45=0.22)$. In other words, couples with a love marriage and no wedding ceremony are 0.2 times less likely to co-reside than couples with an arranged marriage and a go-between from the husband's kinship or neighborhood.

Table 7 about here

Table 8 shows the results of a comparative analysis for patrilocal co-residence in which the sample was divided into the 1930s and 1940s cohorts born before the high economic growth period and the 1950s and 1960s cohorts born during the high economic growth period ${ }^{12}$. The former cohorts are the demographic transitional generation, and the latter cohorts correspond to the children of the transitional generation - that is, the post-transitional generation of low fertility coupled with low mortality.

Table 8. about here

Conjugal family ideology: Love marriage has a powerful effect that can reduce by half the likelihood of co-residence upon marriage. However, the coefficient of love marriage turns to be positive after marriage (but not significant), suggesting the effect is limited to the time of marriage and does not have any effect on delayed co-residence. Looking at the type of go-between, couples who had a wedding ceremony without a go-between and couples who did not have a wedding

\footnotetext{
12 For a cohort comparison, the observation period is restricted to 15 years since marriage, because the mean and standard deviation of time duration (the number of years since marriage) for the younger cohorts are 8.43 and 6.41, respectively.
} 
ceremony at all were significantly less likely to co-reside upon marriage relative to couples who had a traditional wedding ceremony with a go-between from the husband's kin/neighborhood. This negative association is stronger in younger cohorts upon marriage. However, it appears to decline over time as well as in love marriages. Table 9 presents the results of selected variables (categories) from separated models for co-residence less than five years after marriage and five to fifteen years after marriage, restricted to the 1950s and 1960s cohorts. The negative effects of no go-between and "no wedding ceremony" on co-residence are becoming weaker over time, and the latter effect even turns out to be positive (but not significant).

Thus, the two variables entered in the model as measures of conjugal family ideology are negatively associated with co-residence upon marriage, consistent with theoretical expectations. Despite the strong effects at the time of marriage, their effects on delayed co-residence decline over time, which is not consistent with the family nuclearization theory.

Table 9 about here

Industrialization and the spread of higher education: Couples in which the husband is a regular employee are 0.42 times less likely to co-reside than couples in which the husband is self-employed. This result is similar between the transitional and post-transitional generations, indicating that the change in occupational structure accompanied by industrialization is strongly associated with the decrease in co-residence upon marriage. However, there are no significant effects of the husband's employment status on co-residence after marriage. Thus, not only the conjugal family but also the stem family could functionally fit modern industry under some conditions. With regard to educational attainment, couples in which the husband is a university graduate are 0.64 times less likely to co-reside upon marriage than those with less education. On the other hand, the wife's educational attainment has no significant effect on co-residence upon marriage, suggesting a tendency among highly educated women to marry highly educated men. In addition, both the husband and wife's education show no significant association with co-residence after marriage at the $5 \%$ level.

Industrialization and the spread of higher education thus work to decrease the overall likelihood of co-residence at the time of marriage. However, the fact that they have little effect on delayed co-residence is of great interest.

Urbanization: Couples living in large cities are 0.17 times less likely to co-reside upon marriage than those living in rural areas. With regard to after marriage, the former is 0.59 times less likely to co-reside than the latter. Although the impact of the city size on delayed co-residence is more prominent in younger cohorts, this effect declines over time and turns out to be insignificant after five years of marriage, as shown in Table 9. It indicates that the effect of urbanization should work only in the early years of marriage.

Since an urbanized society is also an industrialized society as well as a highly educated 
society, the concept of urbanization generally connotes some elements of industrialization and higher education. Moreover, the measures of these factors empirically are more or less correlated with each other. As the effects of employment and education are controlled in the models, however, the effect of the city size (net of other variables) indicates urban characteristics other than industrial structures and education. What does this mean?

In view of the factors that directly influence intergenerational co-residence, we should first examine the housing issues. In urban areas, generally speaking, population density is very high and land use is considerably restricted, resulting in a large number of smaller houses. In the high economic growth period, additionally, the young people in the transitional generation migrated to large cities and formed their families. Because many were second and third sons and daughters, they had built small houses in which, at the time, they did not expect to live with their parents. Such houses were standard so-called "n-LDK" types (a few bedrooms, a living room, and a dining room with kitchen) and were sold in very high volumes in urban areas. A small house on a small plot of land for the nuclear household was rational in the short run; however, it can be a restriction for their married child to co-reside at marriage, being unreasonable in the long run. If they co-reside in that house, they need to rebuild it into two-household housing (described later), causing a delay in co-residence. In addition, more condominiums that offer smaller spaces than detached n-LDK type houses have been supplied as urbanization has progressed.

Therefore, we can construct a hypothesis stating that such housing restrictions prevent intergenerational co-residence in the early stage of marriage, by waiting for the proper time to rebuild or remodel the existing house, or move to another house. As stated above, the effect of city size tends to greatly suppress co-residence within five years of marriage, but it vanishes after the fifth year of marriage (Table 9). If city size substantially specified the macro-infrastructural characteristics, its effect should continue to work powerfully in the long term. Yet this is not the case. If city size measures something that individual families can respond to independently, that is, restrictions on urban-type housing, its effect can easily change in the short term.

Furthermore, city size partially can measure the spread of modern ideology. Traditional culture and customs, theoretically speaking, are behavioral forms that have been cultivated and accumulated through the processes of adaptation to the natural environment in the long course of history. Cities are intrinsically artificial spaces, and particularly large cities are separated from the region's ecosystem through the extensive use of energy, which weakens cultural restrictions and makes it possible for people to easily accept foreign ideologies. It is therefore reasonable to assume that city size measures the spread of modern ideology-other than that of the conjugal family, which is controlled in the models.

Home ownership, succession/inheritance, and intergenerational reciprocity: As already noted, the number of couples obtaining their home increases over time, and the measure was entered into the models as a time-varying variable. The results reveal that the transfer of property from parents is strongly associated with intergenerational co-residence. The provision of house 
and/or land increases the likelihood of co-residence four times compared to when the home is not yet owned. Financial support also increases the likelihood of co-residence by almost twofold. These effects of intergenerational transfers from the husband's side are stronger in younger cohorts than in older cohorts. In particular, the likelihood of co-residence among couples who are provided a house and/or land in the former cohorts is nearly twice that of co-residence among their counterparts in the latter cohorts. Thus, the association between intergenerational transfers of family property and co-residence, contrary to the family nuclearization theory, has not become weaker but has become even stronger in the post-transitional generation than the transitional generation.

Obtaining a home on their own (without any parental provisions) has a significant effect on co-residence, implying a so-called "taking-in-parents" type of co-residence in which parents come to co-reside in the house obtained by their married child. Many family sociologists in Japan have tended to regard this type of co-residence as a conjugal family variant; however, this view is not consistent with the results shown in Table 8: Obtaining a home on their own is significantly associated with co-residence only in older cohorts. Stated differently, "taking-in-parents" co-residence in the transitional generation is not reproduced in the post-transitional generation. In contrast, the latter has a strong tendency to co-reside in the house owned by their parents in the former generation. What does this mean?

In the cases of "taking-in-parents" co-residence in the transitional generation, parents (G1) moved into the house built by their married son (G2), who had migrated from their home village to the city in the high economic growth period. Their married child of the next generation (G3), typically the eldest son, who had grown up in this house, would sooner or later co-reside with his parents (G2) after the death of co-residing grandparents (G1) and succeed the house and/or land. In short, this means that the basis of family reproduction had moved from the ancestral village to the city between the pre-transitional generation (G1) and the post-transitional generation (G3). Therefore, it is appropriate to regard "taking-in-parents" co-residence as a temporary and intermediate step of stem family reproduction caused by migration, rather than viewing it as a variant of the conjugal family.

As has been repeatedly stated, those born in the 1960s are primarily children of the transitional generation who experienced rural-urban migration. Therefore, many of the 1960s cohort were raised in urban areas. Most of their parents were able to obtain home ownership by virtue of the high economic growth. In fact, the NFRJ-S01 data shows that $78 \%$ of those born in the 1930s and 1940s own their home at the time of survey, whereas $80 \%$ of those born in the 1960s answered that their parents owned their home when they were 15 years old. Delayed co-residence is premised on the high prevalence of home ownership.

With regard to the status of heirs, couples in which the husband is the eldest son are about seven times more likely to co-reside both upon and after marriage than couples in which the husband is the other son. As is the case with intergenerational transfer, the effect of the eldest son in younger cohorts is stronger than in older cohorts, especially among couples in which the husband and wife are both the eldest, independent of the effect of sibling size. Moreover, the effect of the 
eldest son increases over time (Table 9). The principle of eldest son preference in patrilocal co-residence is intact even in the post-transitional generation.

Furthermore, the association between intergenerational reciprocity and co-residence in younger cohorts seems to be stronger than in older cohorts-namely, the death of a parent significantly increases the likelihood of co-residing upon and after marriage with the parent left behind by two to three times compared to when both parents are alive, only in the young cohorts. However, the existence of young child(ren) or the need for childcare is significantly associated with co-residence for both younger and older cohorts. Interestingly, the likelihood of co-residence rises as the child(ren) get older, implying not only the necessity of grandparenting but also the necessity of rooms (or larger housing) for the teenage children.

In summary, although the increase in housing restrictions accompanied by urbanization causes some difficulties in co-residence upon marriage, the intergenerational transfer and reciprocity between parents and their eldest son have resulted in co-residence sometime after marriage among those born in the 1960s. Of particular importance is the fact that the family property obtained during the period of high economic growth has been passed down to the younger generation via delayed co-residence, disproving the family nuclearization hypothesis and suggesting that the stem family principle of succession/inheritance remains as strong as ever.

Period effect and regional variation: No significant differences are shown in the likelihood of co-residence upon marriage between the marriage cohorts of 1959 or earlier, 1960-1969, and 1970-1979 in Table 7, and also between the marriage cohorts of 1979 or earlier and 1980-1984 in Table 8, suggesting that the decrease in co-residence upon marriage is primarily accounted for by the explanatory variables until the mid-1980s. However, the cohort of 1990s in Table 7 and the cohorts of 1985-1989 and 1990 or later in Table 8 show significantly negative effects, indicating that the decrease in co-residence upon marriage during and after the bubble economy period (1987-1991) is not fully accounted for by the explanatory variables. What are the factors that are yet to be identified?

The key to unraveling the answer to this question lies in the fact that marriage cohorts have almost no significant effect on delayed co-residence. If the period effect from the mid-1980s onward substantively represents a macro-structural or institutional factor, it should have a similar impact on co-residence after marriage as it does on co-residence upon marriage. However, this is not the case, which suggests that the effect of the marriage cohort is of a similar type to that of conjugal family ideology. In fact, the ideology of individualism accompanied by the neoliberal ideology and policies has spread rapidly during and after the bubble economy period (Kato 2011). Love marriage and the type of go-between (especially no go-between and no wedding ceremony) can measure the acceptance of individualist ideology as well as conjugal family ideology. Yet, at the same time, it is difficult to cover the whole of such ideologies with these measures alone. Therefore, there is a strong possibility that the effect of the marriage cohort, which turned out to be significant after the mid-1980s, indicates an ideological effect that could not be specified by the ideology 
measures (net of other variables) included in the model.

Looking at the region of residence, the likelihood of patrilocal co-residence upon marriage is two times higher among residents in Tohoku/Northern Kanto (North East Japan) and Chubu (Central East Japan) than it is in the reference region, Southern Kanto (near the Tokyo metropolitan area). On the other hand, residents in Kinki (Central West, the area surrounding Osaka) have a lower likelihood of co-residence after marriage than other areas. It is very interesting that these figures correspond to the family regionality elucidated by sociologists and anthropologists who had investigated rural families and villages - that is, two types of the stem family in Japan: the North Eastern type and the South Western type.

- Discrete-time logistic regression models for matrilocal co-residence

Although the descriptive analysis conducted in the previous section showed a consistently low level of matrilocal co-residence over the life course, the author also estimates discrete-time logistic regression models for matrilocal co-residence in order to depict a whole picture of the Japanese family system. The analytic sample sizes, after dropping cases with missing data on any of the variables in the models, are 3,021 individual respondents for co-residence upon marriage and 58,928 person-year observations for that after marriage. Table 10 provides descriptive statistics for explanatory and control variables and the odds ratios from the models.

Table 10 about here

Love marriage has a negative effect on the likelihood of matrilocal co-residence upon marriage, however, it turns to be positive after marriage. Couples who had a wedding ceremony with a go-between from the wife's side are about 3 times more likely to co-reside upon marriage and about 2 times more likely to co-reside after marriage with the wife's parent(s), relative to couples who had a go-between from the husband' side.

The husband's non-regular employment and unemployment are positively associated with matrilocal co-residence both upon and after marriage, while such couples are only 3 percent of the sample. On the other hand, the wife's regular employment is positively associated with delayed co-residence, implying the necessity of grandparenting to allow the wife to work fulltime. Residence in large city as well as small regional city has a strong negative effect on co-residence upon marriage, yet it turns to be positive soon after marriage (not significant), suggesting the restrictions on urban-type housing as discussed earlier. The wife's parents might strategically remodel or rebuild their house if they have a chance to co-reside than the husband's parents.

The provision of house, land, and/or financial support from the wife's side increases the likelihood of delayed co-residence 3.4 times compared to when the home is not yet owned. Home ownership "upon marriage" shows not a positive effect but a negative effect on matrilocal co-residence, however, it is because most of obtaining home upon marriage occurred through 
patrilocal co-residence and succession simultaneously. The death of father significantly increases the likelihood of co-residing with a mother both upon and after marriage, compared to when both parents are alive. With regard to the status of heirs, couples in which the husband is the other son are two to five times more likely to co-reside both upon and after marriage than couples in which the husband is the eldest son. Moreover, the number of wife's siblings had strong negative effects on matrilocal co-residence, which is decisive if the wife is the only child, implying that parents without sons tend to provide family property in order to co-reside with married daughter.

The marriage cohort is negatively associated with matrilocal co-residence upon marriage but positively related to that after marriage, suggesting an ideological effect, as discussed earlier, that could not be specified by the ideology measures (net of other variables) included in the model.

In sum, although the spread of modern ideology as well as the increase in housing restrictions accompanied by urbanization reduce the likelihood of co-residing with the wife's parent(s) upon marriage, the intergenerational transfer and reciprocity cause delayed co-residence among married daughters with few brothers of the post-transitional generation. The mechanism behind matrilocal co-residence is consistent with the traditional mukoyoshi practice in which the husband is taken into the wife's family substantively.

\section{Proximate residence with parents and the multi-household stem family}

When we think of the traditional stem family, we tend to have a stereotypical image of a family in which three generations, including the parents, the couple of the heir, and the grandchildren, all live under the same roof. Such a family is the single-household-type stem family featured in North East Japan, where three generations co-reside in one family home sharing living expenses. By contrast, the multi-household-type stem family has been in existence in South West Japan and along the Pacific coast of East Japan. In a multi-household stem family, the parents and the couple of the heir live by separating their households into a main house and its annex on the same premise or in the adjacent neighborhood (Gamo 1960; Shimizu 1986; Kumagai 2008; Kato 2009).

Even today, there are many three-generation families where parents live with their married children in the same building but in separate households, in different buildings on the same premises or in the neighborhood. The so-called "two-household housing" that has been built in cities since the 1980s is often advertised as "a new style of co-residence that respects the privacy of parents and their married children," but we can also regard it as a type of traditional multi-household stem family. Two-household housing refers to detached housing with two each of kitchens, bathrooms, and entrances in the same detached house, allowing couples of two generations to live in separate households - typically with the older couple on the ground floor and the younger couple on the first floor. There are variations among such housing, with some types only separating kitchens and other types completely separating all facilities except the internal connecting door.

In the Population Census, the latter types with a higher degree of separation are counted as 
two nuclear family households, because the couples must "share living quarters and living expenses" in order to be defined as a single household, as mentioned earlier ${ }^{13}$. Recently, the production volume of two-household housing has been rapidly expanding since the bubble economy period, and major house manufacturers have been publicizing new home designs every year ${ }^{14}$. Therefore, it should be noted that delayed co-residence, as shown in Figures 1 to 4, could include some types of two-household housing because the definition of co-residence used in the questionnaire was left to the respondents to interpret it. Moreover, those in North East Japan tend to have a broader concept of co-residence, owing to their long tradition of single-household stem families. The increase in two-household housing, then, could lead to the rise in the number of nuclear family households in the Population Census, showing the "fictitious nuclearization."

Figure 5 displays the shares of people co-residing in extended family households by prefecture in 1960 (left) and 2000 (right) using the Census. We can easily find clear east-west contrasts in both maps (except Hokkaido, the northern island ${ }^{15}$ ), although the levels in 2000 are about $15 \%$ lower than those in 2000, mainly because of the decrease in intergenerational co-residence at marriage, and secondly owing to the increase in the highly separated types of two-household housing.

Figure 5 about here

With regard to the distribution of multi-household stem families, we do not have any data in the Census but have some measures in a few nationally representative cross-sectional surveys ${ }^{16}$. The Comprehensive Survey of Living Conditions (started in 1986) is the only survey conducted by the Government that has detailed information about intergenerational proximate residence. Figure 6 presents the share of the elderly aged 65 or older who live close to their child(ren) in the same building but in separate households, in different buildings on the same premises, or in the neighborhood in 2001. Although the data include the living arrangements with their unmarried child(ren) as well as married child(ren), an east-west gradient is visible in this measure of the multi-household stem family.

Figure 6 about here

\footnotetext{
13 See also note 1.

14 According to the Nikkei (Japanese newspaper), the amount of orders for two-household housing that Asahi Kasei Homes, the leading company in two-household housing, received from April to October 2011 rose 8.4\%, compared to a year earlier (Nihon Keizai Shinbun 2011).

15 Hokkaido had been colonized by the central government and settled by a large number of immigrants from all over Japan during the late ninetieth and the early twentieth century. This island had no specific family tradition, thus it was excluded from consideration of cultural regionality here.

${ }^{16}$ The National Family Research of Japan 2003 (NFRJ03), conducted by the Japan Society of Family Sociology) also collected the detailed cross-sectional data on intergenerational proximate residence as well as co-residence. The maps using the data displays a similar east-west contrasts to Figure 5 and 6 (Kato 2009).
} 
There are no national data on household composition before 1960, however, the number of marital units per household (MUH) can be used for a measure of the single-household stem family. Figure 7 depicts the MUH measure by prefecture in 1886 (left) and 1920 (right), which is obtained by dividing the number of married females by the number of households in a prefecture ${ }^{17}$. There are clear east-west gradients visible in both maps, implying a persistent contrast of two types of stem family ${ }^{18}$.

Figure 7 about here

In order to evaluate multi-household stem families, the NFRJ-S01 collected event history data on the proximate residence within walking distance to parents. Figure 8 plots a similar type of graph to the co-residence in Figure 1. The proportions of living nearby the husband's parent(s) or the wife's parent(s) are at a level of around 20\% from the time of marriage onward. Although they are slightly higher in the 1920s and 1960s cohorts than in the 1930s and 1940s cohorts that experienced massive domestic migration, the cohort differences are relatively small throughout. Additionally, when plotting graphs of patrilocal and matrilocal proximate residence separately, they are similar to Figure 8 (not shown).

Figure 8 about here

Using this data, the author estimates discrete-time logistic regression models for patrilocal and matrilocal proximate residence. The observation period is restricted to ten years since marriage, as $95 \%$ of the events occurred during the period. The models include the same set of explanatory and control variables as the models for intergenerational co-residence, except for a category of region of residence in the early years of marriage. That is, "Chugoku/Shikoku/Kyushu” is divided into the north and south of the region, "Chugoku and Northern Kyushu" and "Shikoku and Southern Kyushu," based on the distribution of multi-household stem families shown in Figure 6. In addition, intergenerational co-residence is regarded as a competing risk. In other words, if the respondents co-reside with the husband's or the wife's parent(s) at year t, then they are censored hereafter. It is because there can be some systematic differences between the mechanisms behind proximate residence after co-residence and the direct one, but there are a small number of those who cease to co-reside with their parents and begin to live nearby. Also, the author estimates separate models for patrilocal proximate residence and matrilocal proximate residence such as the models for co-residence.

\footnotetext{
${ }^{17}$ The MUH is usually obtained by dividing the sum of absolute numbers of married, widowed, and divorced males, as well as of widowed and divorced females, by the total number of households in a given region (Szołtysek 2010). However, the author used the number of married females as a numerator, because married men are more likely to work away from home leaving their spouses, children, and parents behind than married women in Japan. In addition, there are no data on the widowed and the divorced in 1886. See also Hayami and Kurosu (2001) for the MUH in 1886.

${ }^{18}$ The MUH measure in 1960 shows the mean of 1.01, a standard deviation of 0.07, and almost the same contrast as Figure 5 (left).
} 
Table 11 summarizes the results of major causes from the models. Couples with love marriage are 1.7 times more likely to live nearby the wife's parent(s) than those with arranged marriage, suggesting the shift from matrilocal co-residence to proximate residence in the early years of marriage, although the cohort differences are small for both living arrangements.

The wife's regular employment is positively associated with both patrilocal and matrilocal proximate residence, and her self-employment increases the likelihood of the latter. On the other hand, the husband's regular employment is significantly associated with neither patrilocal nor matrilocal proximate residence, but his self-employment in non-agriculture raises the likelihood of the former (significant at $1 \%$ level, not shown in the table).

Table 11 about here

The intergenerational transfer of family property has crucial effects on both patrilocal and matrilocal proximate residence. In contrast to patrilocal co-residence, however, couples in which the husband is the eldest son are less likely to live nearby the husband's parent(s) than couples in which the husband is the other son. These results suggest the establishment of a branch family household by non-heir son close to the main family household where parents live with their eldest son. Yet it should be noted that rural sociologists and anthropologists revealed the ultimogeniture practice (inheritance by the youngest child) as well as partible (but non-equal) inheritance in South Western Japan, more specifically in Southern Kyushu in the mid-twentieth century (Takeda 1970; Naito 1973). Therefore, it is probable that other sons as heirs live close to their parents and succeed the family property in the region. In fact, the likelihood of patrilocal proximate residence is about 1.5 times higher among residents in Kinki and in Shikoku/Southern Kyushu, consistent with this interpretation. Futhermore, the likelihood of matrilocal proximate residence is about 1.5 times higher among those in Tohoku/Northern Kanto and in Shikoku/Southern Kyushu, which might be related to mukoyoshi practice in East Japan and succession by the youngest daughter in West Japan respectively, whereas the birth order of couple has no significant effect on matrilocal proximate residence.

To sum up, intergenerational proximate residence is based on the transfer of family property, suggesting the continuity of the multi-household-type stem family as well as that of single-household type. Therefore, we can integrate intergenerational co-residence (Figure 1) with proximate residence (Figure 8) in the same graph. As depicted in Figure 9, the combination of co-residence and proximate residence forms lines that are $20 \%$ higher overall than the lines in Figure 1. Over half of couples in the post-transitional generation are in intergenerational co-residence or proximate residence in the middle years of marriage onward, which presents the full scope of stem family residence encompassing two types of stem family.

Figure 9 about here 


\section{Conclusion and Discussion}

The results from the discrete-time logistic regression analysis revealed that the spread of conjugal family ideology, industrialization, and urbanization are the primary causes of the decrease in intergenerational co-residence at marriage. Although all of the factors associated with neolocal residence strongly affect couples at the time of marriage, they start to weaken immediately and then fade out sooner or later, suggesting the "temporal neolocal residence" limited to the early years of marriage. In other words, this is nothing more than "fictitious nuclearization" (Harada 1978), which does not accompany a transition to the conjugal family system.

Conjugal family ideology, which was originally the traditional view of the family in northwestern Europe, especially England, was eagerly introduced to Japan during the postwar “democratization reforms" to replace the prewar "ie family ideology." Since the period of high economic growth, concepts and images derived from conjugal family ideology have been imported on a large scale through various media and have spread among young people, helped in part by their adoration of America's consumer society. Although people may admire the new ideology, the indigenization is not such a simple matter, as with other foreign ideologies such as individualism: New values originated in different cultures tend to be in strong conflict with the customs and practices embedded in people throughout history, even if people approve of them. In other words, there is a huge gap between ideals and practices, which is why the effect of conjugal family ideology on intergenerational co-residence is rapidly declining over time.

The same line of argumentation holds for the effect of urbanization fading over time. As stated above, it could not be macro-structural but micro-structural urbanization, such as the availability of houses, or housing restrictions. In particular, the 3LDK type of house or condominium is indeed the "receptacle" of a nuclear family, comprised of a couple's bedroom, two children's rooms, a dining room with kitchen, and a living room for the family to relax together. This housing style emerged at the end of the high economic growth period and remains the standard after entering the twenty-first century. Yuko Nishikawa (2000) points out in her study overviewing the modern history of the family and housing that "the 3LDK design is featured by the normativeness that compels the residing family to be an average nuclear family.” Stated differently, 3LDK-type housing, which does not assume future co-residence with married child, is a product of the conjugal family ideology. Moreover, the administrative term of "standard household," which refers to the nuclear family household with a couple and two children, has resulted in housing restrictions to prevent intergenerational co-residence through urban policies. In view of Nishikawa's study, it is probable to interpret the effect of urbanization as an indirect effect of the ideology.

Why is the husband's employment status associated with intergenerational co-residence solely at the time of marriage as well? The classical theory of family nuclearization is based on the assumption that industrial society is a society with a high degree of mobility. However, modern Japanese society is a highly sedentary society, as demonstrated by the high proportion of home ownership. Domestic migration is generally a flow of people from local or urban areas, and most of 
it takes place among young people before marriage, which is linked to massive employment of new graduates, lifetime employment, and a low level of unforced job changing. On the other hand, post-marital migration is limited to male employees who work for large-scale companies involved in inter-regional or nationwide business. Even among them, it is generally the case that they are posted to distant branch offices or factories, leaving their wives and children behind with the intention of returning in about three or four years. Thus, in Japan, modern industry has adjusted to the high sedentariness of the society. Furthermore, the post-transitional generation, who are children of the transitional and migratory generation, are primarily urban residents; most could have a geographical condition allowing for intergenerational co-residence. These accounts would offer a reasonable interpretation of our finding that occupational structure does not have a negative effect on delayed co-residence.

As stated earlier, Goode considered conjugal family ideology as an independent factor that precedes industrialization and urbanization. In line with Goode's expectation, the spread of the ideology is the primary force in the decrease in intergenerational co-residence at the time of marriage in Japan in the latter half of the twentieth century. By contrast, urbanization and the change in occupational structure would be intermediate factors.

Inconsistent with Goode's expectation, however, the negative impact of conjugal family ideology on intergenerational co-residence has a very short duration, suggesting another prerequisite for the system change toward the conjugal family; the migratory culture as an independent factor should precede the ideology. Furthermore, we could speculate that the conjugal family itself originated in a society with a long tradition of high geographical mobility, such as northwestern European countries surrounding the North Sea, featured by maritime people in ancient times and by weak family ties (Reher 1998) discussed in the contemporary demography.

While the effects of ideology, industry, and urbanity decline over time, the principle of succession/inheritance as well as intergenerational reciprocity has powerful impacts from the time of marriage onward, never weakening with the passing of time. This feature is clearer among those in the post-transitional generation than among their parents in the transitional generation, suggesting intrinsic forces that form stem families continue to work in depth. Moreover, there has been a long-standing east-west contrast of two types of stem family over the twentieth century, concluding that the Japanese family is still based on the stem family system.

From a theoretical point of view, the concept of multi-household-type stem family is important, which could provide an insight into the variation of family systems. Conventionally, the stem family is defined, in terms of household formation rules, as a multigenerational co-resident group with no more than one married child (Ruggles 2010) or as a household of parent(s) co-residing with a "conjugal family unit" (CFU) of a child, child-in-law, or grandchild (Gruber and Szołtysek 2012). However, it is not the case in Japanese multi-household stem families. For example, if we define the stem family system by household formation rules solely, then we should view the Japanese Imperial Family as a group of conjugal families. The CFU of Emperor dose not co-reside with but lives close to the CFU of Crown Prince. On the other hand, if we regard the 
Imperial Family, which has maintained the family line at least 1,500 years, as a multi-household stem family, we should define the stem family system in terms of the succession principle of family property. As stated earlier, there have been a large number of multi-household stem families among ordinary people in which the CFUs of parents and married child live separately on the same plot of land or in the neighborhood in both historical and contemporary Japan. They should also share some family property, especially land, as suggested by the strong association between intergenerational proximate residence and the transfer of land (Table 11), although some part of property inherited by non-heir child(ren) non-equally. This suggests that family systems should be defined primarily by succession/inheritance principle, secondly by co-residence rules, and the latter might be measures of the former. Further theoretical investigations are needed for the definition of family systems.

From a comparative perspective, the concept of multi-household-type stem family could also provide some insights into the variation of family systems in historical Europe. As shown in Figure 7, the levels of MUH in 1886 appear to be very low (mean of 0.96), relative to those in 1885 in Germany (mean of 1.08) presented by Szołtysek et al. (2010), ${ }^{19}$ owing to multi-household stem families distributed across South West Japan. However, southern regions of Germany display lower MUH values (about 1.00), which implies that there might be a similar type of stem families to the Japanese multi-household stem family.

In addition, the concept of multi-household-type is applicable to the joint family as well as the stem family, not only because multiple CFUs can live separately together on the same premise shared by them, but also because a very large house is needed for more than three CFUs co-residing and sharing living expenses under the same roof, which might be limited to those in higher social classes.

Furthermore, the concept of multi-household-type or intergenerational proximity could be valuable for understanding family systems in contemporary Europe as well as in historical Europe. The 2004 Survey of Health, Ageing and Retirement in Europe (SHARE) revealed not only a North-South divide but also a gradient in living arrangements (Kohli et al. 2005): The proportions of Europeans aged 50 or older co-residing with their child(ren) in the same household among those who have at least one living child demonstrate a North-South divide; The proportions of Europeans aged 50 or older co-residing or living separately in the same building display a North-South gradient, with the Scandinavian countries (Sweden, Denmark, and Netherlands) having the least extended family residence, the South European countries (Spain, Italy, and Greece) having the most extended one, and the other continental countries (France, Germany, Austria, and Switzerland) lying somewhere in-between.

There have been three major views on the regionality in European family systems - that is, the classical East-West divide proposed by Hajnal (1982), the "transitional zone” between the East and West (Szołtysek 2007, 2012), and “strong and weak family systems” (Reher 1998). The concept

\footnotetext{
${ }^{19}$ See Figure 4a and Table 2 in Szołtysek et al. (2010) for details for the distributions of MUH in 1885.
} 
of multi-household-type could shed light on the way to reconciliation of conflicting perspectives. Comparative demographic studies are needed between Japan and European countries, both in the past and the present.

\section{Acknowledgement}

The author gratefully acknowledges the permission of the NFRJ Committee of the Japan Society of Family Sociology to use the NFRJ-S01 data. For this analysis, the datasets were provided by the Social Science Japan Data Archive, Center for Social Research and Data Archives, Institute of Social Science, The University of Tokyo.

\section{References}

Allison, Paul D. 1984. Event History Analysis: Regression for Longitudinal Event Data. Newbury Park: Sage Publications.

Aruga, Kisaemon. 1972. Ie, 'Nihon no Kazoku' Kaidai [Ie: Revising the Title of 'The Japanese Family' ], Tokyo: Shibundo.

Fuse, Akiko. 1993. Kekkon to Kazoku [Marriage and the Family]. Tokyo: Iwanami Shoten.

Gamo, Masao. 1960. Nihonjin no Seikatsu Kouzou Josetsu [Introduction to the Japanese Social Structure]. Tokyo: Seishin Shobo.

Goode, William J. 1963. World Revolution and Family Patterns. New York: Free Press.

Gruber, Siegfried and Mikołaj Szołtysek. 2012. "Stem families, joint families, and the European pattern: What kind of a reconsideration do we need?,” Journal of Family History, 37: 105.

Hajnal, John. 1982. “Two kinds of preindustrial household formation system,” Population and Development Review 8(3): 449-494.

Harada, Takashi. 1978. "Kazoku keitai-no hendo to rojin dokyo fuyo” [Changes in family forms and caregiving for elderly co-resident parents], Japanese Sociological Review 29(1): 50-66.

Hayami, Akira and Kurosu Satomi. 2001, "Regional diversity in demographic and family patterns in preindustrial Japan,” Journal of Japanese Studies 27(2): 295-321.

Hirosima, Kiyoshi. 1997. "Setai kozo-no henka” [Changes in household structure], in Makoto Atoh and Hiroyuki Kanekiyo (eds.), Jinko to Kazoku [Population and the Family].Tokyo: Taimeido, pp.46-49.

Ito, Tatsuya. 1994. Seikatu no naka no Jinko-gaku [Demography in ics within lifestyle]. Tokyo: Kokon Shoin.

Kase, Kazutoshi. 1997. Shudan Shusyoku no Jidai: Kodoseicho no Ninaitetachi [The Age of Mass Domestic Migration: Young workers in the high economic growth]. Tokyo: Aoki Shoten

Kato, Akihiko. 2003a. "Desain to sanpuringu” [Survey design and sampling]. In NFRJ Committee (ed.), Zenkoku Chosa Sengo Nihon no Kazoku no Ayumi Houkokusyo [The National Family Research of Japan Special Survey 2001: Report for Grant-in-Aid for Scientific Research of Japan Society for the Promotion of Science (2001-2002)]. Tokyo: Committee of National Family Research of Japan, Japan Society of Family Sociology, pp.1-11.

Kato, Akihiko. 2003b. Kazoku Hendou no Shakaigakuteki Kenkyuu: Gendai Nihonkazoku no Jizoku to Henyou [A 
Sociological Study of Family Change: Continuity and Change in the Japanese Family]. Ph.D.dissertation., Department of Sociology, Waseda University, Tokyo.

Kato, Akihiko. 2006. "Sengo nihon kazoku no kiseki [Continuity and change in the post-war Japanese family].” In Tomita, Takeshi and Jyonfa Ri (eds.), Kazoku no Henyo to Gender: Shoshi Koureika to Grobaruka no naka de [Gender and Family Change: In Ageing and Globalizing Society]. Tokyo: Nihon Hyoronsha, pp. 3-30.

Kato, Akihiko. 2009. “The Japanese stem family today,” Sociological Review of Kobe University 26:3-18.

Kato, Akihiko. 2011. "Mikonka wo oshisusumetekita futatsu no chikara” ["Two major factors behind the marriage decline in Japan: the deterioration in macroeconomic performance and the diffusion of individualism ideology"], Journal of Population Problems 67(2): 3-39.

Kawashima, Takeyoshi. 1948. Nihon Shakai no Kazokuteki Kosei [Familistic Structure of Japanese Society]. Tokyo: Gakuseisha.

Kohli, Martin, Harald Künemund, and Jörg Lüdicke. 2005. “Family structure, proximity, and contact,” In Börsch-Supan, Axel Börsch-Supan, Agar Brugiavini, Hendrik Jürges, Johan Mackenbach, Johannes Siegrist, and Guglielmo Weber (eds.), Health, Ageing and Retirement in Europe: First Results from the Survey of Health, Ageing and Retirement in Europe. Mannheim, Germany: MEA., pp. 164-170.

Kumagai, Fumie, 2008, Families in Japan: Changes, Continuities, and Regional Variations, Lanham: University Press of America.

Meguro, Yoriko. 1999. "Soron nihon no kazoku no kindaisei: Henka no shuren to tayoka no yukue” [Overview of modernism in the Japanese family: Convergence and divergence], in Yoriko Meguro and Hideki Watanabe (eds.), Koza Shakaigaku 2: Kazoku [Lectures in Sociology 2: The family]. Tokyo: University of Tokyo Press, pp.1-19.

Morgan , S. Philip and Kiyosi Hirosima. 1983. "The persistence of extended family residence in Japan: Anachronism or alternative strategy?,” American Sociological Review 48(2): 269-281.

Morioka, Kiyomi. 1972. "Kazoku no hendo” [Family change], in Kiyomi Morioka (eds.), Shakaigaku Koza 3: Kazoku Shakaigaku [Lectures in Sociology 3: Family Sociology]. Tokyo: University of Tokyo Press, pp. 205-228.

Morioka, Kiyomi. 1993. Gendai Kazoku Hendoron [Theory of Modern Family Change]. Kyoto: Mineruba Shobo.

Morioka, Kiyomi. 2005. Hatten suru Kazoku Shakaigaku: Keisho, Sesshu, Sozo [Developing Family Sociology: Succession, Assimilation and Creation). Tokyo: Yuhikaku.

Naito, Kanji. 1973. Masshi Sozoku no Kenkyu [The study of Ultimogeniture]. Tokyo: Kobundo.

NFRJ Committee. 2003. Zenkoku Chosa Sengo Nihon no Kazoku no Ayumi Houkokusyo [The National Family Research of Japan Special Survey 2001: Report for Grant-in-Aid for Scientific Research of Japan Society for the Promotion of Science (2001-2002)]. Tokyo: Committee of National Family Research of Japan, Japan Society of Family Sociology.

Nihon Keizai Sinbun. 2011. “30 40dai, nisetai jutaku de 'anshin' kazoku ishiki tsuyomaru” [Increase in two-household housing and family security among those aged 30s and 40s], The Nikkei Online Edition, December 5, 2011.

Nishikawa, Yuko. 2000. Kindai Kokka to Kazoku Moderu [The Modern Nation-state and the Family Ideology], Yoshikawa Kobunkan.

Ochiai, Emiko. 1994. 21 Seiki Kazoku e: Kazoku no Sengo Taisei no Mikata Koekata [The Japanese Family System in Transition: a Sociological Analysis of Family Change in Postwar Japan]. Tokyo: Yuhikaku.

Ogawa, Naohiro and Robert D. Retherford. 1997. "Shifting Costs of Caring for the Elderly Back to Families in Japan: 
Will It Work?,” Population and Development Review 23(1): 59-94.

Ogburn, William F. and Meyer F. Nimkoff. 1955. Technology and the Changing Family, Boston: Houghton Mifflin.

Okui, Asako. 2011. Noson-toshi Ido to Kazoku Hendo no Rekishi Shakaigaku: Kingendai Nihon ni okeru 'Kindai

Kazoku no Taishuka’ Saiko [Historical Sociology of Rural-urban Migration and Family Change: Reconsidering the 'Popularization of Modern Family' in Japan]. Kyoto: Koyo Shobo.

Raymo, James M., Letizia Mencarini, Miho Iwasawa and Rie Moriizumi. 2010. "Intergenerational Proximity and the Fertility Intentions of Married Women,” Asian Population Studies 6(2): 193-214..

Reher, David Sven. 1998. “Family Ties in Western Europe: Persistent Contrasts,” Population and Development Review 24(2): 203-234.

Ruggles, Steven. 2010. “Stem Families and Joint Families in Comparative Historical Perspective,” Population and Development Review 36(3): 563-577.

Shorter, Edward. 1975. The Making of the Modern Family. New York: Basic Books.

Shimizu, Hiroaki. 1986. Jinko to Kazoku no Shakaigaku [Sociology of Family and Population]. Tokyo: Saishobo.

Szołtysek, Mikołaj. 2007. “Central European household and family systems, and the 'Hajnal-Mitterauer' line: The parish of Bujakow (18th-19th centuries),” The History of the Family, 12(1): 19-42.

Szołtysek, Mikołaj. 2012. "Spatial construction of European family and household systems: a promising path or a blind alley? An Eastern European perspective,” Continuity and Change, 27: 11-52.

Szołtysek, Mikołaj, Siegfried Gruber, Sebastian Klüsener, and Joshua R. Goldstein. 2010. "Spatial variation in household structure in 19th-century Germany,” MPIDR Working Paper WP 2010-030.

Takeda, Akira. 1970. Ie o Meguru Minzoku Kenkyu [Folk Customs Concerning the “Ie” Household]. Tokyo: Kobundo.

Yamada, Masahiro. 1994. Kindai Kazoku no Yukue: Kazoku to Aijyo no Paradokkusu [Future of the Modern Family: Paradoxes of Family Love]. Tokyo: Shinyosha.

Yamaguchi, Kazuo. 1991. Event History Analysis. Newbury Park: Sage Publications. 
Figures, Tables, and Maps

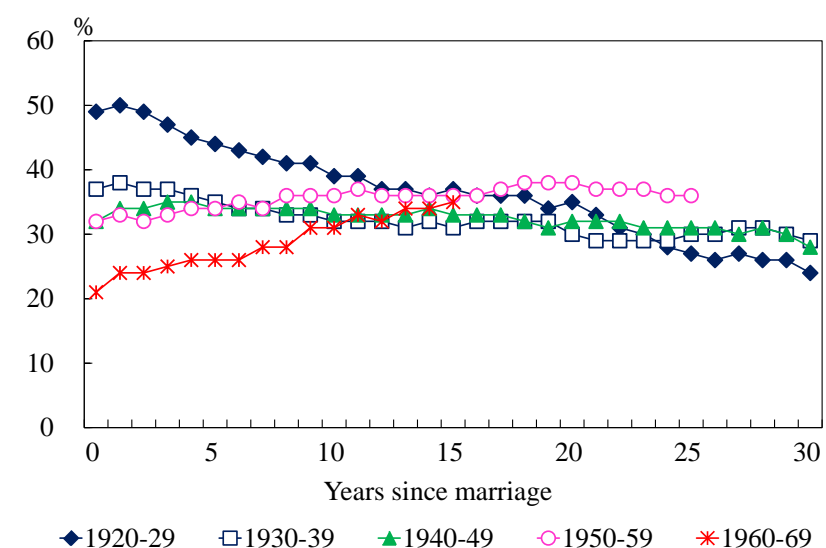

Figure 1. Patrilocal or matrilocal co-residence by wife's birth cohort

Note. The sample is restricted to those who remain in their first marriage and have at least one parent alive among four parents in year $t$.

Patrilocal co-residence

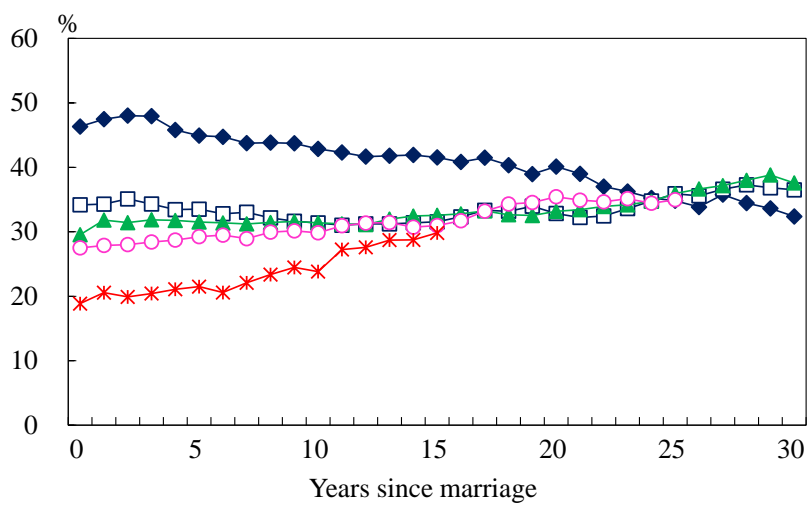

$\diamond$ 1920-29 ㄴ1930-39 $₫ 1940-49 \quad-0-1950-59 \quad * 1960-69$
Matrilocal co-residence

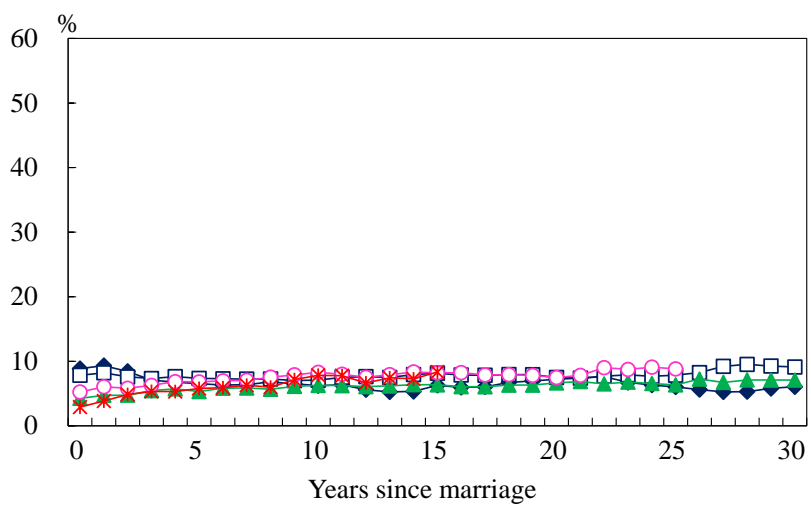

• 1920-29 ㅁ-1930-39 §-1940-49 -0-1950-59 *1960-69

Figure 2. Patrilocal co-residence and matrilocal co-residence by wife's birth cohort

Note. The sample is restricted to those who remain in their first marriage and have at least one parent alive in year $\mathrm{t}$. 
Entire country

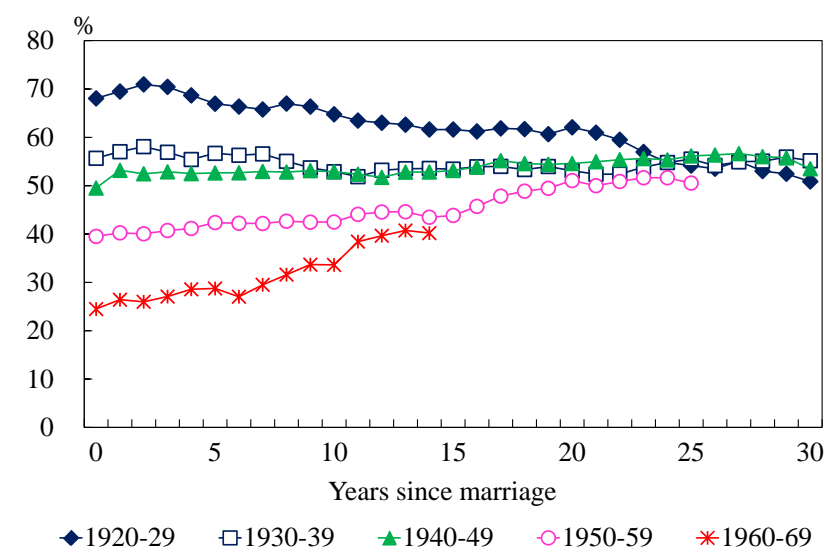

Urban areas

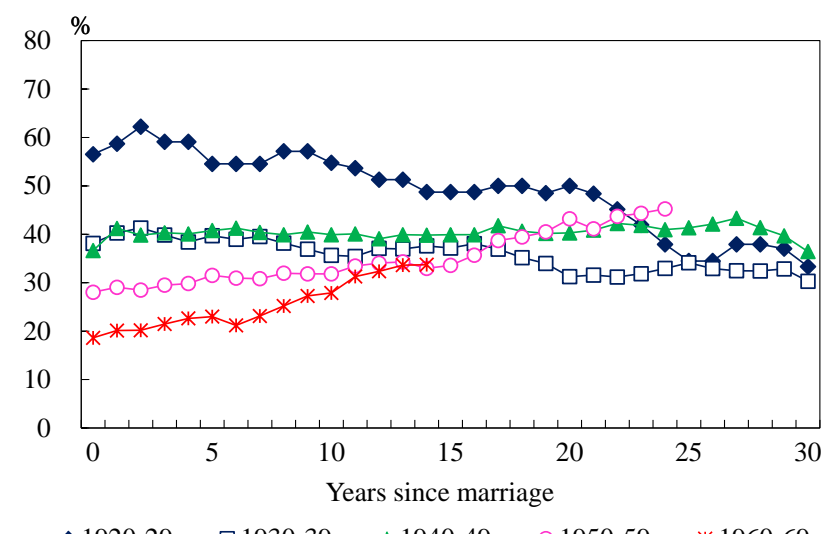

$\bullet$-1920-29 -1930-39 -1940-49 - -1950-59 *1960-69

Figure 3. Patrilocal co-residence of eldest sons by wife's birth cohort: entire country and urban areas

Note. The sample is restricted to those whose husband is the eldest son and who remain in their first marriage and have at least one parent alive in year $\mathrm{t}$.

Patrilocal co-residence

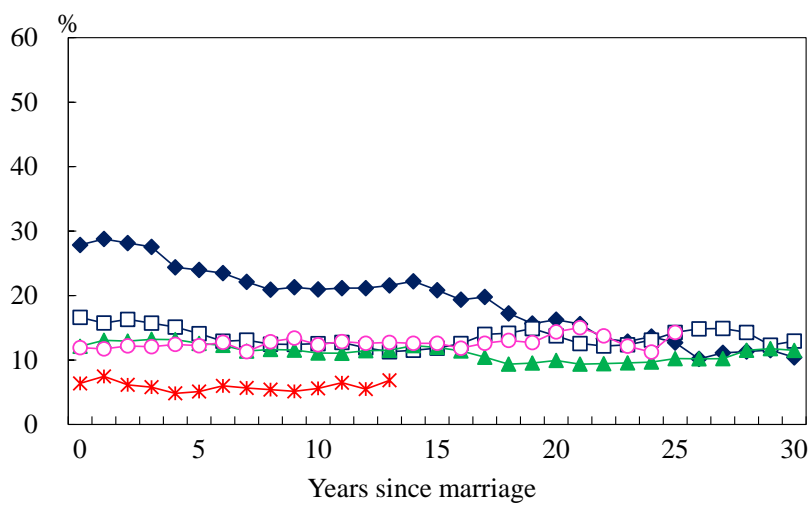

$\bullet$ 1920-29 ㅁ1930-39 -1940-49 -0-1950-59 *1960-69
Matrilocal co-residence

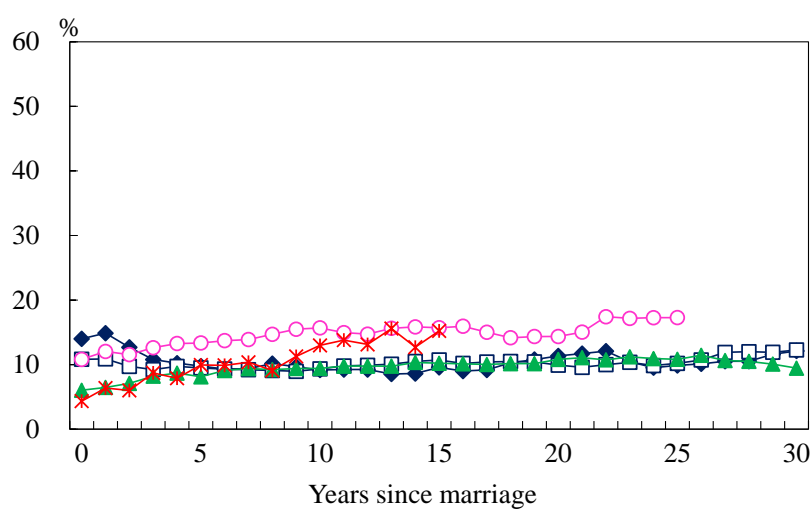

$\bullet 1920-29 \quad \square 1930-39 \quad \$ 1940-49 \quad-0-1950-59 \quad * 1960-69$

Figure 4. Patrilocal co-residence and matrilocal co-residence of other sons by wife's birth cohort Note. The sample is restricted to those whose husband is not the eldest son and who remain in their first marriage and have at least one parent alive in year $\mathrm{t}$. 
Table 1. Love marriage and arranged marriage by marriage cohort (\%)

\begin{tabular}{cccccc}
\hline $\begin{array}{c}\text { Marriage } \\
\text { Cohort }\end{array}$ & Total & $(\mathrm{n})$ & $\begin{array}{c}\text { Love } \\
\text { marriage }\end{array}$ & $\begin{array}{c}\text { Arranged } \\
\text { marriage }\end{array}$ & $\begin{array}{c}\text { Other/ } \\
\text { unknown }\end{array}$ \\
\hline $1940-49$ & 100 & $(199)$ & 20.1 & 63.8 & 16.1 \\
$1950-59$ & 100 & $(464)$ & 31.9 & 60.6 & 7.5 \\
$1960-69$ & 100 & $(786)$ & 44.1 & 49.7 & 6.2 \\
$1970-79$ & 100 & $(822)$ & 59.4 & 35.4 & 5.2 \\
$1980-89$ & 100 & $(677)$ & 76.5 & 18.6 & 4.9 \\
$1990-99$ & 100 & $(362)$ & 81.5 & 14.1 & 4.4 \\
\hline
\end{tabular}

Table 2. Type of go-between at a wedding ceremony by marriage cohort (\%)

\begin{tabular}{|c|c|c|c|c|c|c|c|c|}
\hline \multirow[b]{2}{*}{$\begin{array}{c}\text { Marriage } \\
\text { cohort }\end{array}$} & \multirow[b]{2}{*}{ Total } & \multirow[b]{2}{*}{ (n) } & \multicolumn{4}{|c|}{ With wedding ceremony } & \multirow[b]{2}{*}{$\begin{array}{c}\text { No } \\
\text { wedding } \\
\text { ceremony }\end{array}$} & \multirow[b]{2}{*}{ Unknown } \\
\hline & & & $\begin{array}{l}\text { Husband's } \\
\text { kin/neighbor }\end{array}$ & $\begin{array}{c}\text { Someone } \\
\text { from } \\
\text { husband's } \\
\text { work/school }\end{array}$ & $\begin{array}{l}\text { Someone } \\
\text { from } \\
\text { wife's side }\end{array}$ & $\begin{array}{c}\text { No } \\
\text { go-between }\end{array}$ & & \\
\hline $1940-49$ & 100 & (199) & 38.7 & 12.6 & 30.7 & 5.0 & 13.1 & - \\
\hline $1950-59$ & 100 & (464) & 42.9 & 12.1 & 26.5 & 6.7 & 11.9 & - \\
\hline $1960-69$ & 100 & (786) & 40.1 & 25.2 & 17.8 & 8.5 & 8.1 & 0.3 \\
\hline 1970-79 & 100 & $(822)$ & 40.5 & 27.9 & 13.4 & 10.6 & 7.4 & 0.2 \\
\hline 1980-89 & 100 & $(677)$ & 34.3 & 38.6 & 5.8 & 12.6 & 8.7 & 0.1 \\
\hline 1990-99 & 100 & $(362)$ & 26.2 & 38.7 & 2.5 & 22.4 & 10.2 & - \\
\hline
\end{tabular}

Table 3. Employment status at the time of marriage by marriage cohort (\%)

a) Husband

\begin{tabular}{cccccccc}
\hline $\begin{array}{c}\text { Marriage } \\
\text { cohort }\end{array}$ & Total & (n) & $\begin{array}{c}\text { Self-employed } \\
\text { in agriculture }\end{array}$ & $\begin{array}{c}\text { Self-employed } \\
\text { in non-agriculture }\end{array}$ & $\begin{array}{c}\text { Regular } \\
\text { employee }\end{array}$ & $\begin{array}{c}\text { Non-regular } \\
\text { employee/ } \\
\text { not working }\end{array}$ & Unknown \\
\hline $1940-49$ & 100 & $(199)$ & 22.1 & 8.5 & 57.8 & 10.1 & 1.5 \\
$1950-59$ & 100 & $(464)$ & 18.5 & 14.4 & 59.9 & 6.0 & 1.1 \\
$1960-69$ & 100 & $(786)$ & 6.4 & 15.4 & 74.7 & 2.7 & 0.9 \\
$1970-79$ & 100 & $(822)$ & 3.4 & 10.7 & 82.1 & 2.9 & 0.9 \\
$1980-89$ & 100 & $(677)$ & 2.1 & 7.4 & 87.7 & 2.4 & 0.4 \\
$1990-99$ & 100 & $(362)$ & 1.4 & 7.7 & 87.8 & 1.7 & 1.4 \\
\hline
\end{tabular}

b) Wife

\begin{tabular}{cccccccc}
\hline $\begin{array}{c}\text { Marriage } \\
\text { cohort }\end{array}$ & Total & (n) & $\begin{array}{c}\text { Not working } \\
\text { (full-time housewife) }\end{array}$ & $\begin{array}{c}\text { Regular } \\
\text { employee }\end{array}$ & $\begin{array}{c}\text { Self-employed/ } \\
\text { family worker }\end{array}$ & $\begin{array}{c}\text { Non-regular } \\
\text { employee }\end{array}$ & Unknown \\
\hline $1940-49$ & 100 & $(199)$ & 64.8 & 21.6 & 8.5 & 5.0 & - \\
$1950-59$ & 100 & $(464)$ & 56.7 & 29.1 & 9.1 & 5.0 & 0.2 \\
$1960-69$ & 100 & $(786)$ & 41.7 & 45.4 & 7.8 & 4.7 & 0.4 \\
$1970-79$ & 100 & $(822)$ & 35.6 & 53.8 & 4.4 & 5.6 & 0.6 \\
$1980-89$ & 100 & $(677)$ & 26.4 & 61.4 & 4.3 & 7.7 & 0.1 \\
$1990-99$ & 100 & $(362)$ & 19.1 & 64.9 & 3.3 & 12.2 & 0.6 \\
\hline
\end{tabular}


Table 4. Educational attainment by marriage cohort (\%)

a) Husband

\begin{tabular}{cccccrc}
\hline $\begin{array}{c}\text { Marriage } \\
\text { cohort }\end{array}$ & Total & (n) & $\begin{array}{c}\text { Junior high } \\
\text { school or less }\end{array}$ & $\begin{array}{c}\text { High school/ } \\
\text { junior college/ } \\
\text { vocational school }\end{array}$ & $\begin{array}{c}\text { University } \\
\text { or higher }\end{array}$ & Unknown \\
\hline $1940-49$ & 100 & $(199)$ & 64.3 & 24.1 & 10.1 & 1.5 \\
$1950-59$ & 100 & $(464)$ & 46.8 & 43.8 & 8.4 & 1.1 \\
$1960-69$ & 100 & $(786)$ & 33.0 & 48.0 & 18.4 & 0.6 \\
$1970-79$ & 100 & $(822)$ & 20.8 & 50.9 & 27.5 & 0.9 \\
$1980-89$ & 100 & $(677)$ & 8.3 & 54.8 & 36.8 & 0.1 \\
$1990-99$ & 100 & $(362)$ & 3.0 & 49.2 & 47.5 & 0.3 \\
\hline
\end{tabular}

b) Wife

\begin{tabular}{cccccccc}
\hline $\begin{array}{c}\text { Marriage } \\
\text { cohort }\end{array}$ & Total & (n) & $\begin{array}{c}\text { Junior high } \\
\text { school or less }\end{array}$ & High school & $\begin{array}{c}\text { Junior college/ } \\
\text { vocational school }\end{array}$ & $\begin{array}{c}\text { University } \\
\text { or higher }\end{array}$ & Unknown \\
\hline $1940-49$ & 100 & $(199)$ & 66.3 & 29.1 & 3.5 & 0.5 & 0.5 \\
$1950-59$ & 100 & $(464)$ & 49.1 & 44.8 & 5.0 & 0.2 & 0.9 \\
$1960-69$ & 100 & $(786)$ & 38.4 & 48.0 & 10.6 & 2.8 & 0.3 \\
$1970-79$ & 100 & $(822)$ & 17.0 & 59.6 & 15.9 & 7.1 & 0.4 \\
$1980-89$ & 100 & $(677)$ & 4.3 & 56.0 & 29.7 & 10.0 & - \\
$1990-99$ & 100 & $(362)$ & 1.7 & 47.5 & 36.2 & 14.1 & 0.6 \\
\hline
\end{tabular}

Table 5. City size of residence in the early years of marriage by marriage cohort (\%)

\begin{tabular}{ccccccc}
\hline $\begin{array}{c}\text { Marriage } \\
\text { cohort }\end{array}$ & Total & (n) & Rural village & $\begin{array}{c}\text { Small } \\
\text { regional city }\end{array}$ & $\begin{array}{c}\text { Large city or } \\
\text { central regional city }\end{array}$ & Overseas \\
\hline $1940-49$ & 100 & $(199)$ & 56.8 & 22.1 & 19.1 & 2.0 \\
$1950-59$ & 100 & $(464)$ & 44.0 & 30.2 & 25.9 & 0.0 \\
$1960-69$ & 100 & $(786)$ & 27.5 & 39.3 & 33.2 & 0.0 \\
$1970-79$ & 100 & $(822)$ & 23.4 & 39.9 & 36.3 & 0.5 \\
$1980-89$ & 100 & $(677)$ & 19.8 & 43.0 & 37.2 & 0.0 \\
$1990-99$ & 100 & $(362)$ & 16.0 & 45.0 & 38.4 & 0.6 \\
\hline
\end{tabular}

Table 6. Home ownership and intergenerational transfer of family property 12 years after marriage by marriage cohort (\%)

\begin{tabular}{|c|c|c|c|c|c|c|c|c|c|c|}
\hline \multirow[b]{3}{*}{$\begin{array}{c}\text { Marriage } \\
\text { cohort }\end{array}$} & \multirow[b]{3}{*}{ Total } & \multicolumn{2}{|c|}{ Not yet own } & \multicolumn{6}{|c|}{ Own } & \multirow{3}{*}{ Unknown } \\
\hline & & \multirow[b]{2}{*}{ (n) } & & \multirow[b]{2}{*}{$\begin{array}{c}\text { Upon } \\
\text { marriage }\end{array}$} & \multirow[b]{2}{*}{$\begin{array}{c}\text { Without } \\
\text { any provision }\end{array}$} & \multicolumn{2}{|c|}{ Husband's side } & \multicolumn{2}{|c|}{ Wife's side } & \\
\hline & & & & & & $\begin{array}{c}\text { House/ } \\
\text { land }\end{array}$ & $\begin{array}{c}\text { Financial } \\
\text { support }\end{array}$ & $\begin{array}{c}\text { House/ } \\
\text { land }\end{array}$ & $\begin{array}{c}\text { Financial } \\
\text { support }\end{array}$ & \\
\hline $1940-49$ & 100 & (199) & 55.3 & 11.1 & 18.1 & 6.5 & 1.0 & 2.5 & - & 5.5 \\
\hline 1950-59 & 100 & $(464)$ & 59.1 & 10.1 & 20.5 & 5.4 & 0.2 & 2.4 & 0.2 & 2.2 \\
\hline 1960-69 & 100 & (786) & 55.7 & 7.0 & 25.4 & 3.6 & 3.2 & 2.0 & 1.5 & 1.5 \\
\hline $1970-79$ & 100 & (822) & 51.7 & 8.0 & 21.8 & 5.4 & 6.6 & 2.3 & 3.2 & 1.1 \\
\hline 1980-89 & 100 & (677) & 53.0 & 5.3 & 18.3 & 5.5 & 9.6 & 3.1 & 4.1 & 1.0 \\
\hline
\end{tabular}


Table 7. Descriptive statistics and odds ratios from discrete time logistic regression models for patrilocal co-residence

\begin{tabular}{|c|c|c|c|c|}
\hline \multirow[b]{2}{*}{ Variable } & \multicolumn{2}{|c|}{$\begin{array}{l}\text { Descriptive statistics } \\
\text { Mean (SD) }\end{array}$} & \multicolumn{2}{|c|}{$\begin{array}{l}\text { Model estimates } \\
\text { Odds ratios }\end{array}$} \\
\hline & Upon marriage & After marriage & Upon marriage & After marriage \\
\hline Number of years since marriage & - & $10.96(8.01)$ & - & $0.87 * * * *$ \\
\hline \multicolumn{5}{|l|}{ Love marriage } \\
\hline Arranged marriage (ref) & 38.0 & 34.9 & 1.00 & 1.00 \\
\hline Love marriage & 56.1 & 60.0 & $0.48 * * * *$ & 1.19 \\
\hline Other/unknown & 5.9 & 5.1 & 1.09 & $1.76 *$ \\
\hline \multicolumn{5}{|l|}{ The type of go-between at a wedding ceremony } \\
\hline Husband's kin/neighbor (ref) & 38.9 & 34.4 & 1.00 & 1.00 \\
\hline Someone from husband's work/school & 28.3 & 31.0 & 0.94 & $0.70 * *$ \\
\hline Someone from wife's side & 14.4 & 15.4 & $0.60 * * *$ & $0.66 *$ \\
\hline No go-between & 11.3 & 10.4 & $0.70 *$ & 0.86 \\
\hline No wedding ceremony & 7.1 & 8.9 & $0.45 * * *$ & $0.63 *$ \\
\hline \multicolumn{5}{|l|}{ Husband's employment status at marriage } \\
\hline Self-employed in agriculture (ref) & 7.0 & 3.1 & 1.00 & 1.00 \\
\hline Self-employed in non-agriculture & 11.3 & 10.0 & $0.74 \dagger$ & 0.84 \\
\hline Regular employee & 78.6 & 83.1 & $0.42 * * * *$ & 0.79 \\
\hline Non-regular employee/not working & 3.2 & 3.8 & $0.32 * * *$ & 0.43 \\
\hline \multicolumn{5}{|l|}{ Wife's employment status in year t } \\
\hline Not working (ref) & 37.3 & 62.7 & 1.00 & 1.00 \\
\hline Regular employee & 50.3 & 17.8 & 1.07 & 1.04 \\
\hline Self-employed/family worker & 5.9 & 6.1 & 1.19 & 0.68 \\
\hline Non-regular employee & 6.5 & 13.4 & 1.22 & 1.15 \\
\hline \multicolumn{5}{|l|}{ Husband's educational attainment } \\
\hline Junior high school (ref) & 24.2 & 24.1 & 1.00 & 1.00 \\
\hline High school/junior college/vocational school & 49.0 & 47.1 & 1.07 & 1.15 \\
\hline University or higher & 26.8 & 28.8 & $0.64 *$ & 1.16 \\
\hline \multicolumn{5}{|l|}{ Wife’s educational attainment } \\
\hline Junior high school (ref) & 24.1 & 24.1 & 1.00 & 1.00 \\
\hline High school & 51.3 & 51.3 & 1.02 & 1.22 \\
\hline Junior college/vocational school & 18.0 & 17.7 & 0.94 & 1.01 \\
\hline University or higher & 6.6 & 6.9 & 0.88 & 1.17 \\
\hline \multicolumn{5}{|l|}{ City size of residence in the early years of marriage } \\
\hline Rural village (ref) & 24.5 & 15.5 & 1.00 & 1.00 \\
\hline Small regional city & 38.7 & 40.4 & $0.27 * * * *$ & $0.65 *$ \\
\hline Large city/central regional city & 36.8 & 44.1 & $0.17 * * * *$ & $0.59 * *$ \\
\hline
\end{tabular}


Table 7. (continued)

\begin{tabular}{|c|c|c|c|c|}
\hline \multirow[b]{2}{*}{ Variable } & \multicolumn{2}{|c|}{$\begin{array}{l}\text { Descriptive statistics } \\
\text { Mean (SD) }\end{array}$} & \multicolumn{2}{|c|}{$\begin{array}{l}\text { Model estimates } \\
\text { Odds ratios }\end{array}$} \\
\hline & Upon marriage & After marriage & Upon marriage & After marriage \\
\hline \multicolumn{5}{|l|}{ Birth order of husband and wife } \\
\hline Other son and other daughter (ref) & 21.5 & 29.1 & 1.00 & 1.00 \\
\hline Eldest son and other daughter & 25.3 & 17.1 & $6.89 * * * *$ & $6.84 * * * *$ \\
\hline Other son and eldest daughter & 24.9 & 33.8 & $1.50 *$ & 1.15 \\
\hline Eldest son and eldest daughter & 28.4 & 20.1 & $7.62 * * * *$ & $6.43 * * * *$ \\
\hline \multicolumn{5}{|l|}{ Number of husband's siblings } \\
\hline More than 4 (ref) & 49.3 & 59.1 & 1.00 & 1.00 \\
\hline 2 or 3 & 44.4 & 36.8 & $1.92 * * * *$ & 1.03 \\
\hline Only child & 6.3 & 4.2 & $2.44 * * * *$ & 1.08 \\
\hline \multicolumn{5}{|l|}{ Number of wife's siblings } \\
\hline More than 4 & 46.7 & 47.4 & 1.00 & 1.00 \\
\hline 2 or 3 & 48.7 & 46.6 & $0.79 \dagger$ & 0.84 \\
\hline Only child & 4.6 & 6.0 & $0.12 * * * *$ & 0.65 \\
\hline \multicolumn{5}{|c|}{ Home ownership and intergenerational transfer in year t } \\
\hline Not yet own (ref) & 92.6 & 58.4 & 1.00 & 1.00 \\
\hline Upon marriage & 7.4 & 6.0 & $1.74 * *$ & 0.93 \\
\hline Without any provision & - & 21.4 & - & $1.39 \dagger$ \\
\hline House/land from husband's side & - & 3.6 & - & $3.91 * * * *$ \\
\hline Financial support from husband's side & - & 5.1 & - & $1.87 *$ \\
\hline Any provision from wife's side & - & 5.4 & - & 0.69 \\
\hline \multicolumn{5}{|l|}{ Wife's age at marriage } \\
\hline 20 or younger & 9.0 & 9.4 & 1.07 & 1.39 \\
\hline $21-23$ & 29.2 & 28.4 & $1.26 \dagger$ & $1.36 *$ \\
\hline 24-26 (ref) & 37.1 & 40.6 & 1.00 & 1.00 \\
\hline $27-29$ & 15.6 & 14.6 & 1.04 & 1.04 \\
\hline 30 or older & 9.2 & 7.0 & 1.15 & 0.88 \\
\hline \multicolumn{5}{|l|}{ Age of the youngest child in year $t$} \\
\hline Not yet have a child (ref) & - & 12.6 & - & 1.00 \\
\hline $0-6$ & - & 40.1 & - & $1.35 \dagger$ \\
\hline $7-12$ & - & 20.6 & - & 1.31 \\
\hline 13 or older & - & 26.8 & - & $2.74 *$ \\
\hline \multicolumn{5}{|l|}{ Parent(s) alive in year $\mathrm{t}$} \\
\hline Both parents alive (ref) & 76.5 & 60.3 & 1.00 & 1.00 \\
\hline Only mother alive & 18.8 & 32.2 & $1.54 * * *$ & $1.48 * *$ \\
\hline Only father alive & 4.7 & 7.5 & $1.50 \dagger$ & $1.63 *$ \\
\hline
\end{tabular}


Table 7. (continued)

\begin{tabular}{|c|c|c|c|c|}
\hline \multirow[b]{2}{*}{ Variable } & \multicolumn{2}{|c|}{$\begin{array}{l}\text { Descriptive statistics } \\
\text { Mean (SD) }\end{array}$} & \multicolumn{2}{|c|}{$\begin{array}{l}\text { Model estimates } \\
\text { Odds ratios }\end{array}$} \\
\hline & Upon marriage & After marriage & Upon marriage & After marriage \\
\hline \multicolumn{5}{|l|}{ Marriage cohort } \\
\hline 1959 or earlier (ref) & 18.9 & 17.9 & 1.00 & 1.00 \\
\hline $1960-69$ & 23.7 & 28.3 & 0.79 & 0.92 \\
\hline 1970-79 & 25.0 & 28.8 & 1.05 & 1.01 \\
\hline 1980-89 & 20.8 & 18.6 & $0.62 *$ & 0.85 \\
\hline 1990 or later & 11.6 & 6.4 & $0.36 * * * *$ & $0.59 \dagger$ \\
\hline \multicolumn{5}{|c|}{ Region of residence in the early years of marriage } \\
\hline Tohoku/Northern Kanto & 14.6 & 11.5 & $2.27 * * * *$ & 0.92 \\
\hline Southern Kanto (ref) & 23.5 & 27.4 & 1.00 & 1.00 \\
\hline Chubu & 18.1 & 14.7 & $2.04 * * * *$ & 1.27 \\
\hline Kinki & 17.8 & 19.9 & 1.09 & $0.56 * *$ \\
\hline Chugoku/Shikoku/Kyushu & 21.3 & 20.3 & 1.03 & 1.00 \\
\hline Hokkaido & 4.7 & 6.1 & 0.76 & 0.79 \\
\hline Constant & - & - & -0.340 & $-4.577 * * * *$ \\
\hline Number of observations & 2,976 & 36,670 & 2,976 & 36,670 \\
\hline$\chi^{2}$ & - & - & $1,102.06 * * * *$ & $461.04 * * * *$ \\
\hline $\mathrm{df}$ & - & - & 42 & 50 \\
\hline
\end{tabular}

${ }^{* * * *} p<.0001, \quad{ }^{* * *} p<.001, \quad * * p<.01, \quad * p<0.05, \quad \dagger p<0.10$ 
Table 8. Odds ratios from discrete time logistic regression models for patrilocal co-residence: A cohort comparison

\begin{tabular}{|c|c|c|c|c|}
\hline \multirow[b]{2}{*}{ Variable } & \multicolumn{2}{|c|}{$\begin{array}{l}\text { 1930s and } 1940 \text { s cohorts } \\
\text { Odds ratios }\end{array}$} & \multicolumn{2}{|c|}{$\begin{array}{l}1950 \text { s and } 1960 \text { s cohorts } \\
\text { Odds ratios }\end{array}$} \\
\hline & Upon marriage & After marriage & Upon marriage & After marriage \\
\hline Number of years since marriage & - & $0.81 * * * *$ & - & $0.83 * * * *$ \\
\hline \multicolumn{5}{|l|}{ Love marriage } \\
\hline Arranged marriage (ref) & 1.00 & 1.00 & 1.00 & 1.00 \\
\hline Love marriage & $0.47 * * * *$ & 1.10 & $0.61 *$ & 1.41 \\
\hline Other/unknown & 1.41 & 1.19 & 1.67 & $2.38 \dagger$ \\
\hline \multicolumn{5}{|l|}{ The type of go-between at a wedding ceremony } \\
\hline Husband's kin/neighbor (ref) & 1.00 & 1.00 & 1.00 & 1.00 \\
\hline Someone from husband's work/school & 0.74 & $0.46 * *$ & 0.89 & 0.86 \\
\hline Someone from wife's side & $0.51 * * *$ & 0.74 & 0.79 & $0.41 \dagger$ \\
\hline No go-between & 0.67 & 0.68 & $0.62 \dagger$ & 0.78 \\
\hline No wedding ceremony & $0.54 \dagger$ & 0.77 & $0.33 *$ & 0.63 \\
\hline \multicolumn{5}{|l|}{ Husband's employment status at marriage } \\
\hline Self-employed in agriculture (ref) & 1.00 & 1.00 & 1.00 & 1.00 \\
\hline Self-employed in non-agriculture & 0.86 & 1.17 & 0.38 & 0.64 \\
\hline Regular employee & $0.39 * * *$ & 0.91 & $0.29 *$ & 1.01 \\
\hline Non-regular employee/not working & $0.24 * *$ & 0.66 & $0.14 *$ & 0.16 \\
\hline \multicolumn{5}{|l|}{ Wife's employment status in year t } \\
\hline Not working (ref) & 1.00 & 1.00 & 1.00 & 1.00 \\
\hline Regular employee & 1.02 & 1.16 & 1.13 & 1.12 \\
\hline Self-employed/family worker & 1.07 & 0.95 & 1.48 & 0.83 \\
\hline Non-regular employee & 1.56 & 1.22 & 0.81 & $1.87 *$ \\
\hline \multicolumn{5}{|l|}{ Husband's educational attainment } \\
\hline Junior high school (ref) & 1.00 & 1.00 & 1.00 & 1.00 \\
\hline High school/Junior college/vocational school & 1.08 & 1.48 & 0.82 & 0.96 \\
\hline University or higher & $0.60 \dagger$ & 1.41 & $0.50 \dagger$ & 0.83 \\
\hline \multicolumn{5}{|l|}{ Wife’s educational attainment } \\
\hline Junior high school (ref) & 1.00 & 1.00 & 1.00 & 1.00 \\
\hline High school & 1.02 & 1.17 & 0.97 & 0.51 \\
\hline Junior college/vocational school & 1.16 & 1.12 & 0.90 & $0.44 \dagger$ \\
\hline University or higher & 1.88 & 1.74 & 0.66 & 0.53 \\
\hline \multicolumn{5}{|l|}{ City size of residence in the early years of marriage } \\
\hline Rural village (ref) & 1.00 & 1.00 & 1.00 & 1.00 \\
\hline Small regional city & $0.30 * * * *$ & 0.82 & $0.20 * * * *$ & $0.30 * * * *$ \\
\hline Large city/central regional city & $0.20 * * * *$ & 0.67 & $0.12 * * * *$ & $0.27 * * * *$ \\
\hline
\end{tabular}


Table 8. (continued)

\begin{tabular}{|c|c|c|c|c|}
\hline \multirow[b]{2}{*}{ Variable } & \multicolumn{2}{|c|}{$\begin{array}{l}\text { 1930s and 1940s cohorts } \\
\text { Odds ratios }\end{array}$} & \multicolumn{2}{|c|}{$\begin{array}{l}1950 \text { s and } 1960 \text { s cohorts } \\
\text { Odds ratios }\end{array}$} \\
\hline & Upon marriage & After marriage & Upon marriage & After marriage \\
\hline Birth order of husband and wife & 1.00 & 1.00 & 1.00 & 1.00 \\
\hline Other son and other daughter (ref) & 1.00 & 1.00 & 1.00 & 1.00 \\
\hline Eldest son and other daughter & $6.93 * * * *$ & $6.99 * * * *$ & $7.93 * * * *$ & $7.72 * * * *$ \\
\hline Other son and eldest daughter & 1.26 & 0.78 & $2.29 *$ & 0.91 \\
\hline Eldest son and eldest daughter & $7.57 * * * *$ & $4.33 * * * *$ & $9.56 * * * *$ & $10.33 * * * *$ \\
\hline \multicolumn{5}{|l|}{ Number of husband's siblings } \\
\hline More than 4 (ref) & 1.00 & 1.00 & 1.00 & 1.00 \\
\hline 2 or 3 & $1.86 * * * *$ & 0.93 & $2.02 * *$ & 0.96 \\
\hline Only child & $2.80 * * *$ & 1.43 & $2.70 * *$ & 0.71 \\
\hline \multicolumn{5}{|l|}{ Number of wife's siblings } \\
\hline More than 4 & 1.00 & 1.00 & 1.00 & 1.00 \\
\hline 2 or 3 & 0.81 & 0.95 & 0.94 & 0.91 \\
\hline Only child & $0.08 * * *$ & 0.56 & $0.17 * *$ & 0.59 \\
\hline \multicolumn{5}{|c|}{ Home ownership and intergenerational transfer in year t } \\
\hline Not yet own (ref) & 1.00 & 1.00 & 1.00 & 1.00 \\
\hline Upon marriage & $1.82 *$ & 1.01 & $2.23 *$ & 0.71 \\
\hline Without any provision & - & $1.87 *$ & - & 1.07 \\
\hline House/land from husband's side & - & $2.67 *$ & - & $5.18 * * * *$ \\
\hline Financial support from husband’s side & - & 0.63 & - & $2.96 * * *$ \\
\hline Any provision from wife's side & - & 0.41 & - & 0.75 \\
\hline \multicolumn{5}{|l|}{ Wife's age at marriage } \\
\hline 20 or younger & 0.78 & 1.11 & $2.01 \dagger$ & 1.21 \\
\hline $21-23$ & 1.05 & 1.21 & $1.58 *$ & $1.90 * *$ \\
\hline 24-26 (ref) & 1.00 & 1.00 & 1.00 & 1.00 \\
\hline $27-29$ & 0.80 & 0.73 & 1.35 & 1.20 \\
\hline 30 or older & 1.41 & 0.62 & 1.08 & 0.97 \\
\hline \multicolumn{5}{|l|}{ Age of the youngest child in year $t$} \\
\hline Do not yet have a child (ref) & - & 1.00 & - & 1.00 \\
\hline $0-6$ & - & $1.74 *$ & - & $2.22 * *$ \\
\hline $7-12$ & - & $2.97 *$ & - & $2.93 *$ \\
\hline 13 or older & - & $6.05 *$ & - & 0.00 \\
\hline \multicolumn{5}{|l|}{ Parent(s) alive in year $\mathrm{t}$} \\
\hline Both parents alive (ref) & 1.00 & 1.00 & 1.00 & 1.00 \\
\hline Only mother alive & 1.18 & 1.25 & $2.19 * * *$ & $1.76^{*}$ \\
\hline Only father alive & 0.89 & 1.45 & $2.67 \dagger$ & $2.61 *$ \\
\hline
\end{tabular}


Table 8. (continued)

\begin{tabular}{|c|c|c|c|c|}
\hline \multirow[b]{2}{*}{ Variable } & \multicolumn{2}{|c|}{$\begin{array}{l}1930 \text { s and } 1940 \text { s cohorts } \\
\text { Odds ratios }\end{array}$} & \multicolumn{2}{|c|}{$\begin{array}{c}\text { 1950s and 1960s cohorts } \\
\text { Odds ratios }\end{array}$} \\
\hline & Upon marriage & After marriage & Upon marriage & After marriage \\
\hline \multicolumn{5}{|l|}{ Marriage cohort } \\
\hline 1959 or earlier (ref) & 1.00 & 1.00 & - & - \\
\hline $1960-64$ & 1.03 & 1.08 & - & - \\
\hline 1965-69 & 0.81 & 0.97 & - & - \\
\hline 1970 or later & 1.14 & 1.07 & - & - \\
\hline 1979 or earlier (ref) & - & - & 1.00 & 1.00 \\
\hline $1980-84$ & - & - & 0.73 & 1.04 \\
\hline 1985-89 & - & - & $0.61 *$ & 0.90 \\
\hline 1990 or later & - & - & $0.43 * *$ & 0.62 \\
\hline \multicolumn{5}{|c|}{ Region of residence in the early years of marriage } \\
\hline Tohoku/Northern Kanto & $1.99 * * *$ & $0.45 *$ & $2.67 * * *$ & 1.01 \\
\hline Southern Kanto (ref) & 1.00 & 1.00 & 1.00 & 1.00 \\
\hline Chubu & $1.35 *$ & 1.09 & $3.43 * * * *$ & $1.79 *$ \\
\hline Kinki & 1.03 & $0.41 * *$ & 1.25 & 0.69 \\
\hline Chugoku/Shikoku/Kyushu & 0.96 & 0.96 & 1.13 & 0.79 \\
\hline Hokkaido & 0.87 & 0.53 & 0.69 & 0.49 \\
\hline Constant & -0.110 & $-4.591 * * * *$ & -0.457 & $-4.079 *$ \\
\hline Number of observations & 1,414 & 12,846 & 1,318 & 11,813 \\
\hline$\chi^{2}$ & $552.08 * * * *$ & $212.36 * * * *$ & $449.89 * * * *$ & $214.63 * * * *$ \\
\hline Df & 41 & 49 & 41 & 49 \\
\hline
\end{tabular}

${ }^{* * * *} p<.0001, \quad{ }^{* * *} p<.001, \quad{ }^{* *} p<.01, \quad * p<0.05, \quad \dagger p<0.10$ 
Table 9. Changes in the effects of selected explanatory variables over time

\begin{tabular}{|c|c|c|c|}
\hline \multirow[b]{2}{*}{ Variable } & \multicolumn{3}{|c|}{$\begin{array}{l}1950 \text { s and } 1960 \text { s cohorts } \\
\text { Odds ratios }\end{array}$} \\
\hline & $\begin{array}{c}\text { Upon } \\
\text { marriage }\end{array}$ & $\begin{array}{l}0-4 \text { years after } \\
\text { marriage }\end{array}$ & $\begin{array}{c}\text { 5-15 years after } \\
\text { marriage }\end{array}$ \\
\hline \multicolumn{4}{|l|}{ Love marriage } \\
\hline Arranged marriage (ref) & 1.00 & 1.00 & 1.00 \\
\hline Love marriage & $0.61 *$ & 1.65 & 1.24 \\
\hline \multicolumn{4}{|l|}{ The type of go-between at wedding ceremony } \\
\hline Husband’s kin/neighbor (ref) & 1.00 & 1.00 & 1.00 \\
\hline No go-between & $0.62 \dagger$ & 0.62 & 0.95 \\
\hline No wedding ceremony & $0.33 *$ & $0.39 \dagger$ & 1.24 \\
\hline \multicolumn{4}{|l|}{ Urban residence in the early years of marriage } \\
\hline Rural village (ref) & 1.00 & 1.00 & 1.00 \\
\hline Small regional city & $0.20 * * * *$ & $0.19 * * * *$ & 0.85 \\
\hline Large city/central regional city & $0.12 * * * *$ & $0.22 * * * *$ & 0.53 \\
\hline \multicolumn{4}{|l|}{ Birth order of husband and wife } \\
\hline Other son and other daughter (ref) & 1.00 & 1.00 & 1.00 \\
\hline Eldest son and other daughter & $7.93 * * * *$ & $6.68 * * * *$ & $13.16 * * * *$ \\
\hline Eldest son and eldest daughter & $9.56 * * * *$ & $12.85 * * * *$ & $10.14 * * * *$ \\
\hline \multicolumn{4}{|c|}{ Home ownership and intergenerational transfer in year t } \\
\hline Not yet own (ref) & 1.00 & 1.00 & 1.00 \\
\hline Upon marriage & $2.23 *$ & 0.45 & 1.52 \\
\hline House/land from husband's side & - & $7.26 * * *$ & $5.97 * *$ \\
\hline Financial support from husband's side & - & $2.96 *$ & $2.92 *$ \\
\hline
\end{tabular}

**** $p<.0001, \quad * * * p<.001, \quad * * p<.01, \quad * p<0.05, \quad \dagger p<0.10$ 
Table 10. Odds ratios from discrete time logistic regression models for matrilocal co-residence

\begin{tabular}{|c|c|c|c|c|}
\hline \multirow[b]{2}{*}{ Variable } & \multicolumn{2}{|c|}{$\begin{array}{l}\text { Descriptive statistics } \\
\text { Mean (SD) }\end{array}$} & \multicolumn{2}{|c|}{$\begin{array}{l}\text { Model estimates } \\
\text { Odds ratios }\end{array}$} \\
\hline & Upon marriage & After marriage & Upon marriage & After marriage \\
\hline Number of years since marriage & - & 11.85(8.24) & - & $0.96 *$ \\
\hline \multicolumn{5}{|l|}{ Love marriage } \\
\hline Arranged marriage (ref) & 38.0 & 41.5 & 1.00 & 1.00 \\
\hline Love marriage & 55.8 & 52.0 & $0.57 *$ & $1.38+$ \\
\hline Other/unknown & 6.2 & 6.5 & 0.67 & 0.83 \\
\hline \multicolumn{5}{|l|}{ The type of go-between at a wedding ceremony } \\
\hline Husband's kin/neighbor (ref) & 38.2 & 40.8 & 1.00 & 1.00 \\
\hline Someone from husband's work/school & 28.4 & 27.6 & 1.10 & 0.84 \\
\hline Someone from wife's side & 14.7 & 15.0 & $2.78 * * * *$ & $1.90 * *$ \\
\hline No go-between & 11.3 & 9.9 & 1.12 & 0.98 \\
\hline No wedding ceremony & 7.3 & 6.8 & 1.06 & 1.25 \\
\hline \multicolumn{5}{|l|}{ Husband's employment status at marriage } \\
\hline Self-employed in agriculture (ref) & 6.7 & 7.7 & 1.00 & 1.00 \\
\hline Self-employed in non-agriculture & 11.2 & 11.6 & 0.93 & $3.19+$ \\
\hline Regular employee & 78.8 & 77.5 & 1.29 & 2.50 \\
\hline Non-regular employee/not working & 3.3 & 3.2 & $2.63+$ & $4.76 *$ \\
\hline \multicolumn{5}{|l|}{ Wife's employment status in year $\mathrm{t}$} \\
\hline Not working (ref) & 37.4 & 61.4 & 1.00 & 1.00 \\
\hline Regular employee & 50.2 & 18.2 & 1.12 & $1.98 * * * *$ \\
\hline Self-employed/family worker & 5.9 & 6.9 & 1.40 & $1.67+$ \\
\hline Non-regular employee & 6.5 & 13.5 & 0.91 & 0.97 \\
\hline \multicolumn{5}{|l|}{ Husband's educational attainment } \\
\hline Junior high school (ref) & 24.4 & 26.8 & 1.00 & 1.00 \\
\hline High school/junior college/vocational school & 48.9 & 48.9 & 1.62 & 0.88 \\
\hline University or higher & 26.7 & 24.3 & 1.12 & 1.02 \\
\hline \multicolumn{5}{|l|}{ Wife's educational attainment } \\
\hline Junior high school (ref) & 24.2 & 28.1 & 1.00 & 1.00 \\
\hline High school & 51.3 & 51.1 & $1.68+$ & 1.26 \\
\hline Junior college/vocational school & 18.0 & 15.3 & 1.33 & 0.97 \\
\hline University or higher & 6.5 & 5.6 & 1.10 & 0.72 \\
\hline \multicolumn{5}{|l|}{ City size of residence in the early years of marriage } \\
\hline Rural village (ref) & 24.1 & 25.5 & 1.00 & 1.00 \\
\hline Small regional city & 39.0 & 38.2 & $0.43 * * *$ & 1.25 \\
\hline Large city/central regional city & 37.0 & 36.3 & $0.27 * * * *$ & 1.44 \\
\hline
\end{tabular}


Table 10. (continued)

\begin{tabular}{|c|c|c|c|c|}
\hline \multirow[b]{2}{*}{ Variable } & \multicolumn{2}{|c|}{$\begin{array}{l}\text { Descriptive statistics } \\
\text { Mean (SD) }\end{array}$} & \multicolumn{2}{|c|}{$\begin{array}{l}\text { Model estimates } \\
\text { Odds ratios }\end{array}$} \\
\hline & Upon marriage & After marriage & Upon marriage & After marriage \\
\hline \multicolumn{5}{|l|}{ Birth order of husband and wife } \\
\hline Other son and other daughter (ref) & 21.7 & 22.3 & 1.00 & 1.00 \\
\hline Eldest son and other daughter & 24.9 & 25.9 & $0.40 * *$ & $0.52 * *$ \\
\hline Other son and eldest daughter & 25.2 & 24.3 & 1.03 & 0.90 \\
\hline Eldest son and eldest daughter & 28.2 & 27.5 & $0.17 * * * *$ & $0.50 * *$ \\
\hline \multicolumn{5}{|l|}{ Number of husband's siblings } \\
\hline More than 4 (ref) & 49.2 & 53.8 & 1.00 & 1.00 \\
\hline 2 or 3 & 44.2 & 39.4 & $0.46 * * *$ & 0.96 \\
\hline Only child & 6.6 & 6.8 & 0.50 & 0.50 \\
\hline \multicolumn{5}{|l|}{ Number of wife's siblings } \\
\hline More than 4 & 46.9 & 54.4 & 1.00 & 1.00 \\
\hline 2 or 3 & 48.6 & 43.5 & $4.51 * * * *$ & $2.94 * * * *$ \\
\hline Only child & 4.5 & 2.2 & $39.10 * * * *$ & $11.34 * * * *$ \\
\hline \multicolumn{5}{|c|}{ Home ownership and intergenerational transfer in year $t$} \\
\hline Not yet own (ref) & 92.6 & 57.4 & 1.00 & 1.00 \\
\hline Upon marriage & 7.4 & 8.5 & $0.35 *$ & 1.16 \\
\hline Without any provision & - & 21.2 & - & 1.26 \\
\hline House/land from husband's side & - & 5.1 & - & 0.78 \\
\hline Financial support from husband's side & - & 4.5 & - & 0.64 \\
\hline Any provision from wife's side & - & 3.2 & - & $3.43 * * * *$ \\
\hline \multicolumn{5}{|l|}{ Wife's age at marriage } \\
\hline 20 or younger & 9.0 & 9.8 & 1.69 & 1.15 \\
\hline $21-23$ & 29.2 & 34.0 & 0.84 & 1.07 \\
\hline 24-26 (ref) & 36.8 & 37.0 & 1.00 & 1.00 \\
\hline $27-29$ & 15.7 & 13.2 & 0.64 & $0.61 *$ \\
\hline 30 or older & 9.2 & 6.1 & 1.04 & 0.76 \\
\hline \multicolumn{5}{|l|}{ Age of the youngest child in year $t$} \\
\hline Not yet have a child (ref) & - & 10.6 & - & 1.00 \\
\hline $0-6$ & - & 37.4 & - & $1.51+$ \\
\hline $7-12$ & - & 21.1 & - & 0.91 \\
\hline 13 or older & - & 31.0 & - & 0.89 \\
\hline \multicolumn{5}{|l|}{ Parent(s) alive in year $t$} \\
\hline Both parents alive (ref) & 80.8 & 63.4 & 1.00 & 1.00 \\
\hline Only mother alive & 14.4 & 28.4 & $2.10 * *$ & $2.86 * * * *$ \\
\hline Only father alive & 4.8 & 8.2 & 0.59 & 1.57 \\
\hline
\end{tabular}


Table 10. (continued)

\begin{tabular}{|c|c|c|c|c|}
\hline \multirow[b]{2}{*}{ Variable } & \multicolumn{2}{|c|}{$\begin{array}{l}\text { Descriptive statistics } \\
\text { Mean (SD) }\end{array}$} & \multicolumn{2}{|c|}{$\begin{array}{l}\text { Model estimates } \\
\text { Odds ratios }\end{array}$} \\
\hline & Upon marriage & After marriage & Upon marriage & After marriage \\
\hline \multicolumn{5}{|l|}{ Marriage cohort } \\
\hline 1959 or earlier (ref) & 19.3 & 22.1 & 1.00 & 1.00 \\
\hline 1960-69 & 23.6 & 28.1 & $0.47 * *$ & 1.54 \\
\hline 1970-79 & 24.7 & 28.8 & $0.42 * *$ & $1.61+$ \\
\hline 1980-89 & 20.8 & 16.2 & $0.33 * *$ & $2.42 * *$ \\
\hline 1990 or later & 11.6 & 4.8 & $0.38+$ & $2.53 *$ \\
\hline \multicolumn{5}{|c|}{ Region of residence in the early years of marriage } \\
\hline Tohoku/Northern Kanto & 14.7 & 14.5 & 0.81 & 0.98 \\
\hline Southern Kanto (ref) & 23.3 & 21.8 & 1.00 & 1.00 \\
\hline Chubu & 18.0 & 18.9 & 0.90 & 0.80 \\
\hline Kinki & 18.0 & 18.6 & 0.60 & 0.83 \\
\hline Chugoku/Shikoku/Kyushu & 21.4 & 21.6 & $0.40 * *$ & 1.14 \\
\hline Hokkaido & 4.6 & 4.6 & 0.43 & 0.93 \\
\hline Constant & - & - & $0.07 * * * *$ & $0.00 * * * *$ \\
\hline Number of observations & 3,021 & 58,928 & 3,021 & 58,928 \\
\hline$\chi^{2}$ & $1,102.06 * * * *$ & $461.04 * * * *$ & $333.03 * * * *$ & $281.49 * * * *$ \\
\hline $\mathrm{df}$ & 42 & 50 & 42 & 50 \\
\hline
\end{tabular}

**** $p<.0001, \quad * * * p<.001, \quad * * p<.01, \quad * p<0.05, \quad \dagger p<0.10$ 


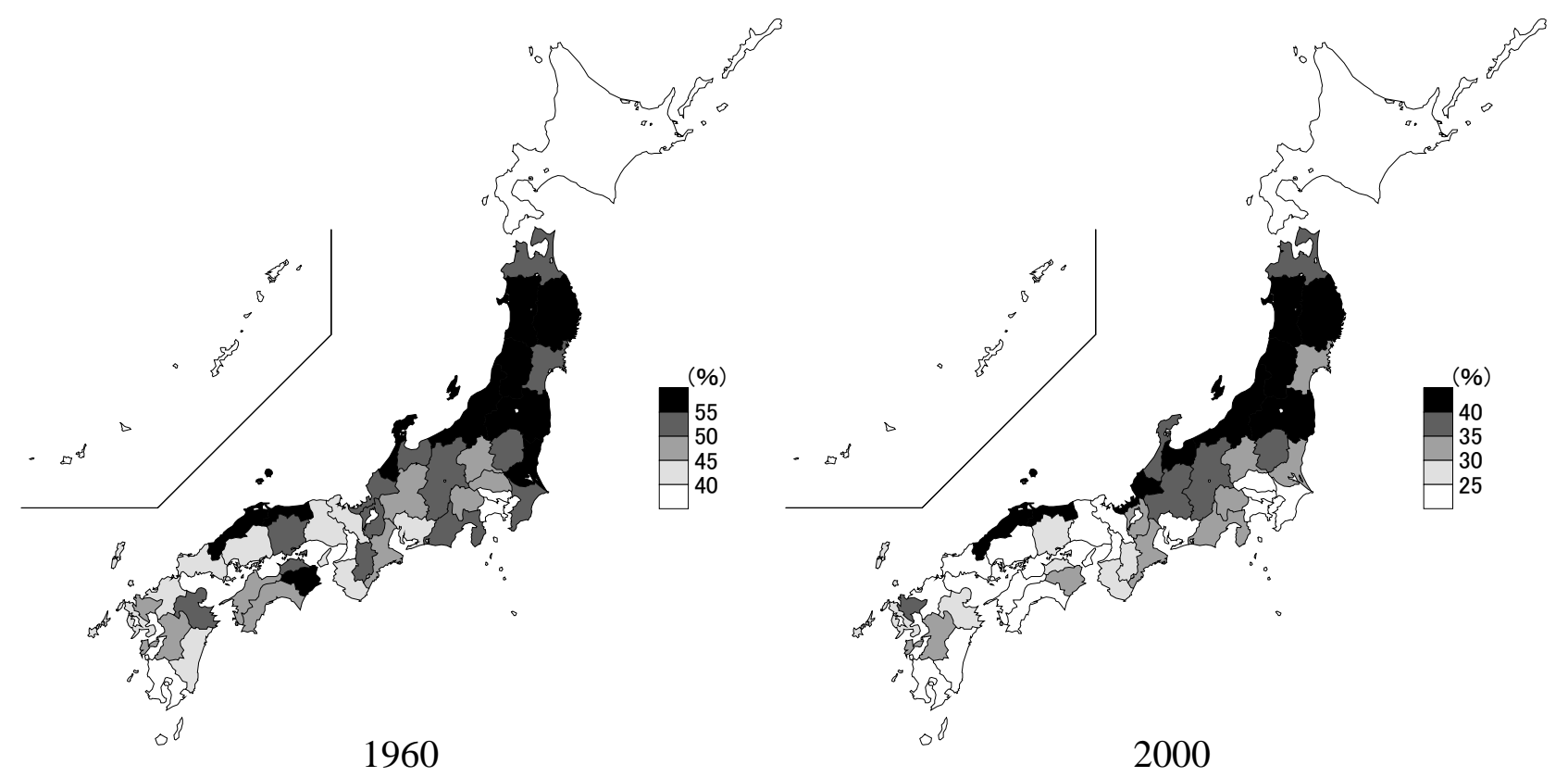

Figure 5. Shares of people co-residing in extended family households by prefecture in 1960 and 2000

Source: Base data from the 1960 and 2000 population censuses of Japan.

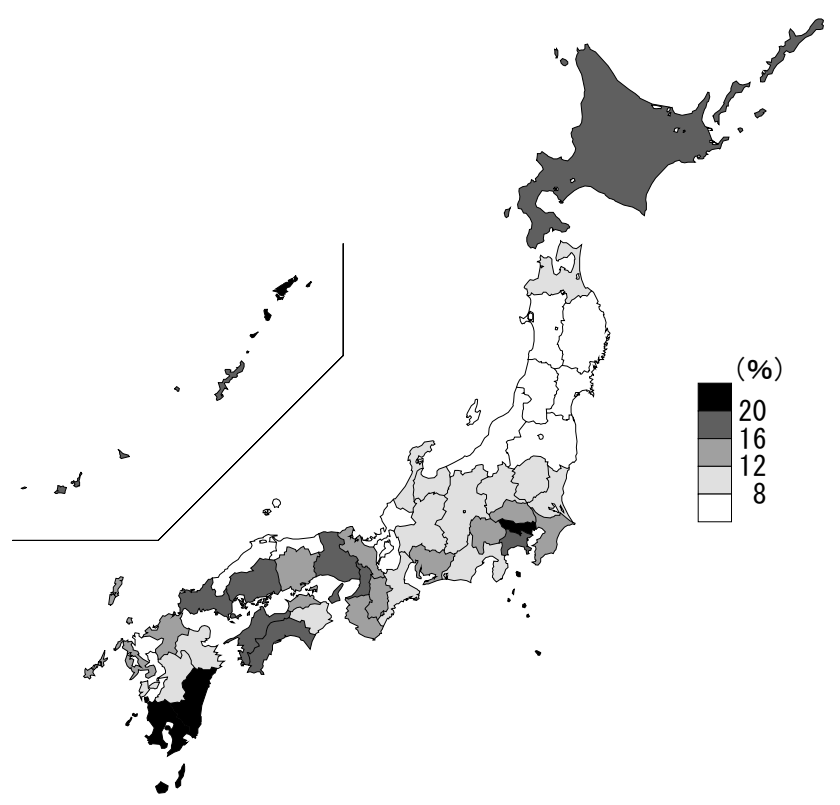

Figure 6. Share of the elderly aged 65 or older who live close to their child(ren) in the same building, on the same premises, or in the neighborhood in 2001 Source: Base data from the 2001 Comprehensive Survey of Living Conditions. 


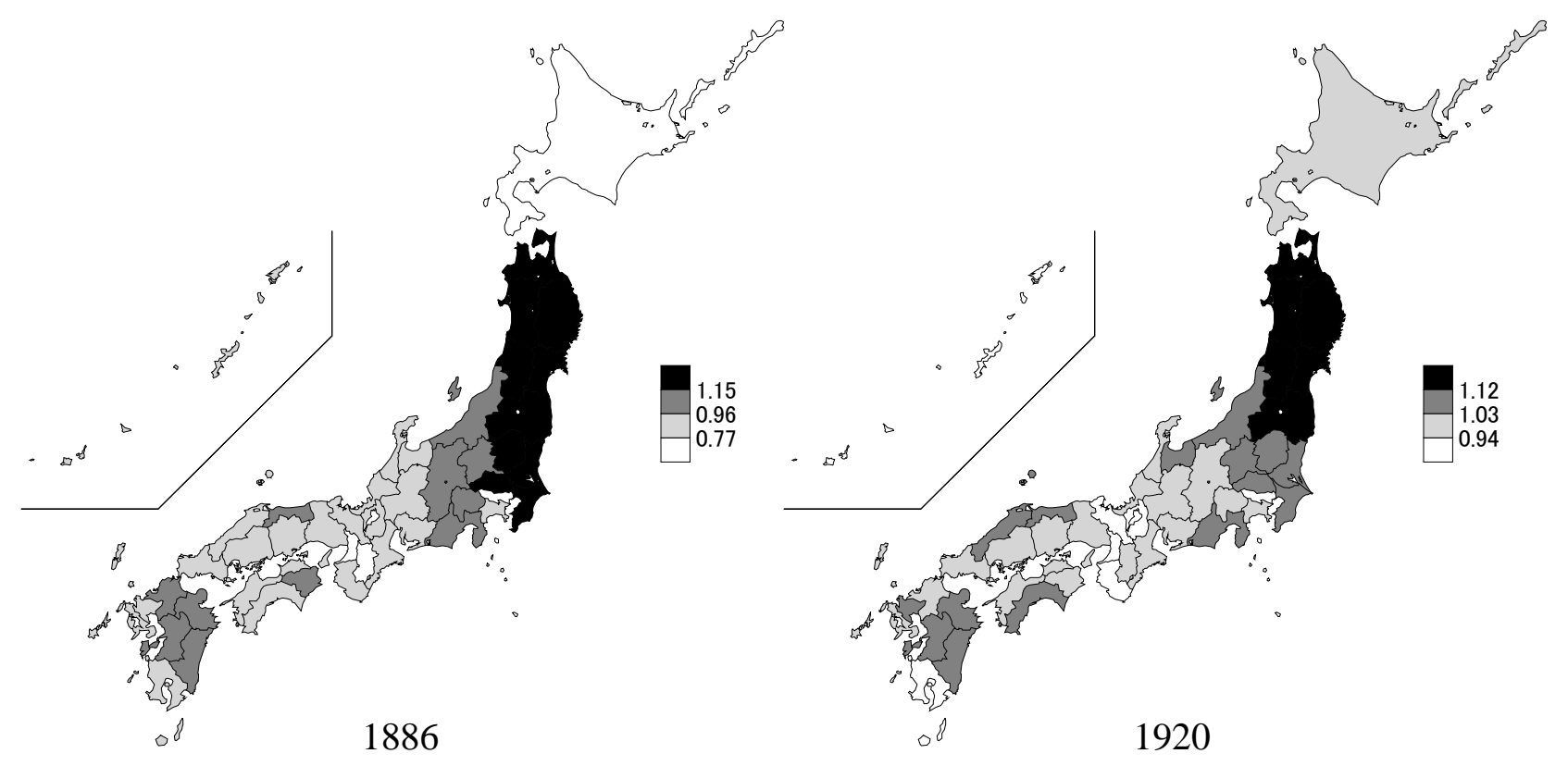

Figure 7. Marital units per household by prefecture in 1886 and 1920

Note: Intervals are based on the mean and the standard deviation.

Source: Base data from the 1886 Nihon Teikoku Minseki KoKohyo (population statistics based on registration) and the 1920 population census of Japan.

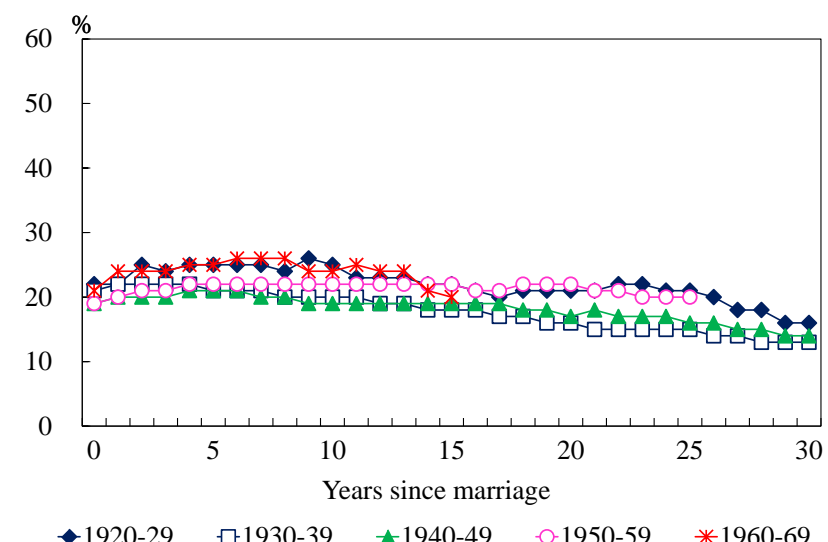

Figure 8. Patrilocal or matrilocal proximate residence by wife's birth cohort

Note. The sample is restricted to those who remain in their first marriage and have at least one parent alive among four parents in year t. 
Table 11. Odds ratios from discrete time logistic regression models for intergenerational proximate residence: Selected variables

\begin{tabular}{|c|c|c|}
\hline Variable & $\begin{array}{l}\text { Patrilocal } \\
\text { proximate } \\
\text { residence }\end{array}$ & $\begin{array}{l}\text { Matrilocal } \\
\text { proximate } \\
\text { residence }\end{array}$ \\
\hline \multicolumn{3}{|l|}{ Love marriage } \\
\hline Arranged marriage (ref) & 1.00 & 1.00 \\
\hline Love marriage & $1.28 \dagger$ & $1.69 * * * *$ \\
\hline Other/unknown & 0.88 & $1.73 * *$ \\
\hline \multicolumn{3}{|l|}{ Wife's employment status in year t } \\
\hline Not working (ref) & 1.00 & 1.00 \\
\hline Regular employee & $1.44 * *$ & $1.31 *$ \\
\hline Self-employed/family worker & 0.96 & $1.72 * *$ \\
\hline Non-regular employee & $1.47 \dagger$ & $1.57 *$ \\
\hline \multicolumn{3}{|l|}{ Birth order of husband and wife } \\
\hline Other son and other daughter (ref) & 1.00 & 1.00 \\
\hline Eldest son and other daughter & $0.54 * * * *$ & 0.88 \\
\hline Other son and eldest daughter & 0.92 & 0.94 \\
\hline Eldest son and eldest daughter & $0.66 *$ & 0.81 \\
\hline \multicolumn{3}{|c|}{ Home ownership and intergenerational transfer in year $\mathrm{t}$} \\
\hline Not yet own (ref) & 1.00 & 1.00 \\
\hline Upon marriage & $3.36 * * * *$ & $0.67 \dagger$ \\
\hline Without any provision & $1.66 *$ & 1.12 \\
\hline House/land from husband's side & $22.10 * * * *$ & 1.67 \\
\hline Financial support from husband's side & $2.94 * *$ & 1.44 \\
\hline Any provision from wife's side & 1.28 & $8.16 * * * *$ \\
\hline \multicolumn{3}{|l|}{ Marriage cohort } \\
\hline 1959 or earlier (ref) & 1.00 & 1.00 \\
\hline 1960-69 & 0.92 & $0.61 * * *$ \\
\hline $1970-79$ & 1.08 & $0.48 * * * *$ \\
\hline 1980-89 & 1.39 & $0.43 * * * *$ \\
\hline 1990 or later & $1.79 *$ & $0.52 * *$ \\
\hline \multicolumn{3}{|c|}{ Region of residence in the early years of marriage } \\
\hline Tohoku/Northern Kanto & 1.11 & $1.50 *$ \\
\hline Southern Kanto (ref) & 1.00 & 1.00 \\
\hline Chubu & 1.01 & 1.06 \\
\hline Kinki & $1.54 * *$ & 1.21 \\
\hline Chugoku/Northern Kyushu & 0.88 & 1.22 \\
\hline Shikoku/Southern Kyushu & $1.68 *$ & $1.42 \dagger$ \\
\hline Hokkaido & 1.29 & 1.13 \\
\hline Constant & $-2.747 * * * *$ & $-2.306 * * * *$ \\
\hline Number of obsevations & 15,695 & 16,591 \\
\hline$\chi^{2}$ & $870.42 * * * *$ & $820.24 * * * *$ \\
\hline df & 50 & 50 \\
\hline
\end{tabular}

**** $p<.0001, \quad * * * p<.001, \quad * * p<.01, \quad * p<0.05, \quad \dagger p<0.10$ 


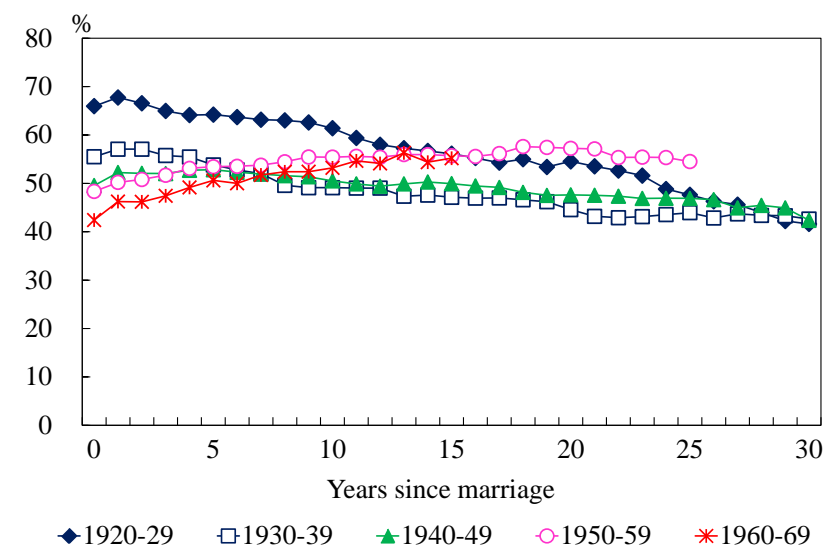

Figure 9. Patrilocal or matrilocal co-residence or proximate residence by wife’s birth cohort

Note. The sample is restricted to those who remain in their first marriage and have at least one parent alive among four parents in year $t$. 